\title{
Building America Research Benchmark Definition, Updated August 15, 2007
}
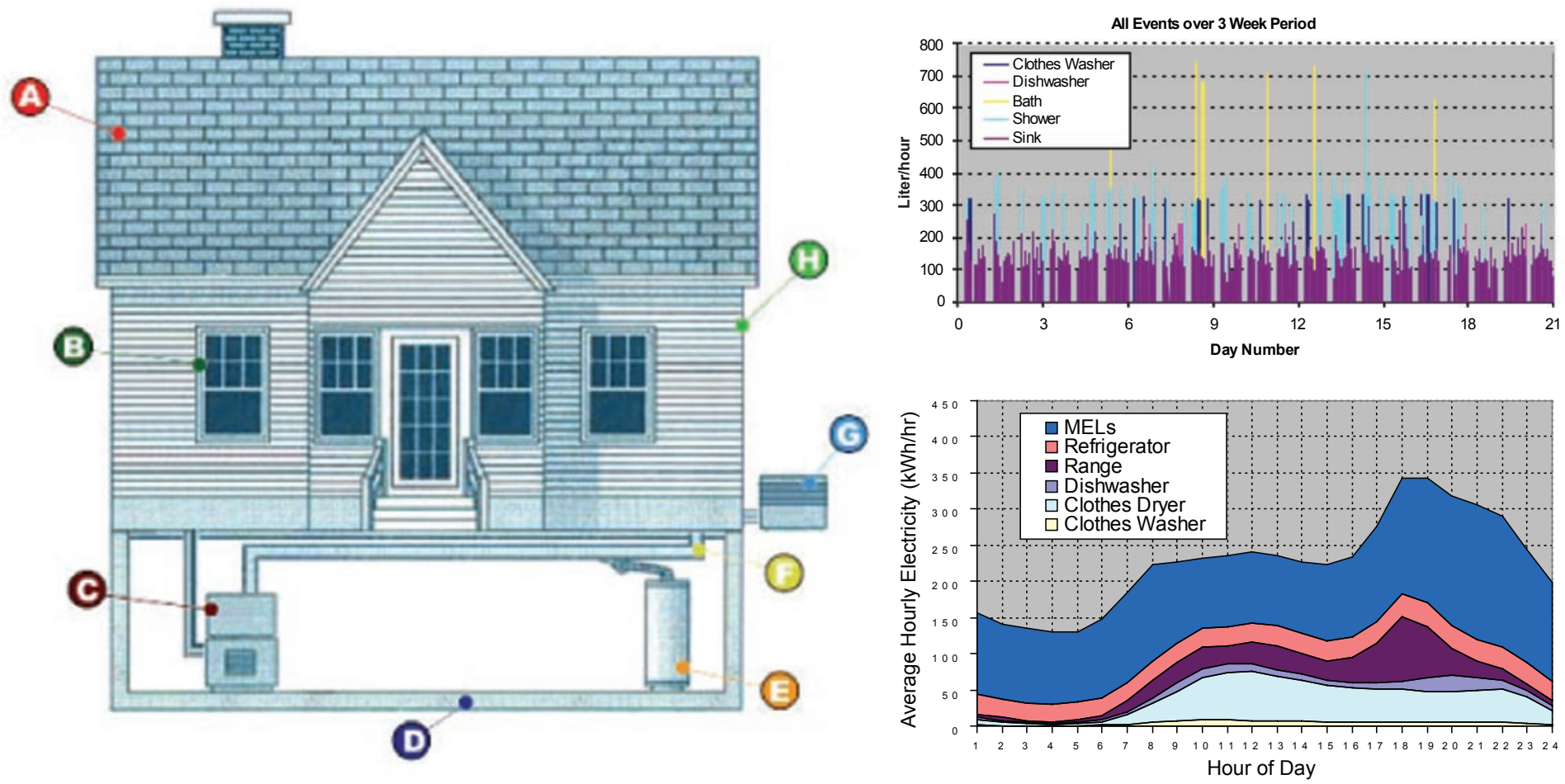

Robert Hendron

National Renewable Energy Laboratory 


\section{Building America Research Benchmark Definition}

\section{Updated August 15, 2007}

R. Hendron

Prepared under Task No. BET78004

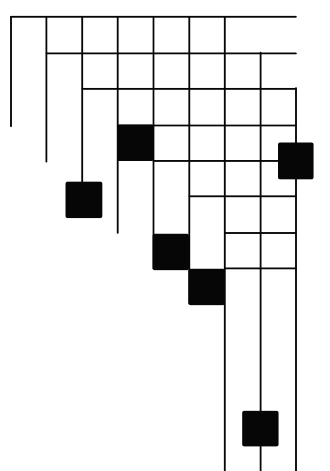




\section{NOTICE}

This report was prepared as an account of work sponsored by an agency of the United States government. Neither the United States government nor any agency thereof, nor any of their employees, makes any warranty, express or implied, or assumes any legal liability or responsibility for the accuracy, completeness, or usefulness of any information, apparatus, product, or process disclosed, or represents that its use would not infringe privately owned rights. Reference herein to any specific commercial product, process, or service by trade name, trademark, manufacturer, or otherwise does not necessarily constitute or imply its endorsement, recommendation, or favoring by the United States government or any agency thereof. The views and opinions of authors expressed herein do not necessarily state or reflect those of the United States government or any agency thereof.

Available electronically at http://www.osti.gov/bridge

Available for a processing fee to U.S. Department of Energy and its contractors, in paper, from:

U.S. Department of Energy

Office of Scientific and Technical Information

P.O. Box 62

Oak Ridge, TN 37831-0062

phone: 865.576 .8401

fax: 865.576 .5728

email: mailto:reports@adonis.osti.gov

Available for sale to the public, in paper, from:

U.S. Department of Commerce

National Technical Information Service

5285 Port Royal Road

Springfield, VA 22161

phone: 800.553.6847

fax: 703.605.6900

email: orders@ntis.fedworld.gov

online ordering: http://www.ntis.gov/ordering.htm 


\section{Table of Contents}

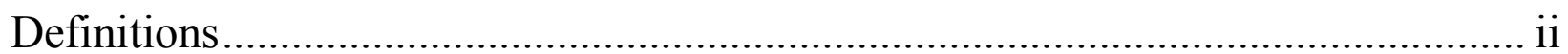

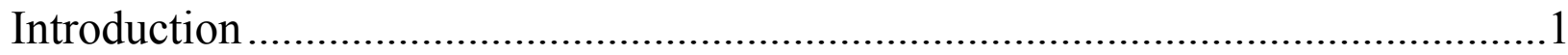

Benchmark House Specifications ......................................................

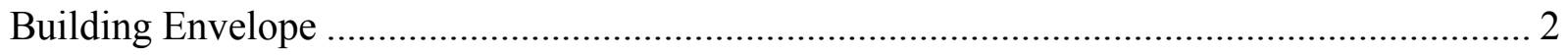

Space Conditioning/Air Distribution Equipment....................................................... 8

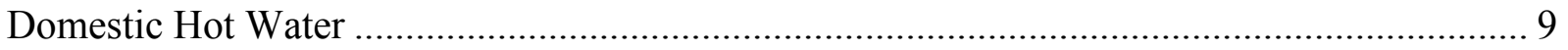

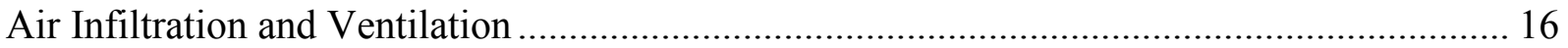

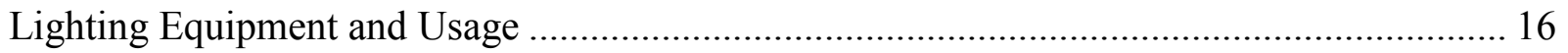

Appliances and Miscellaneous Electric Loads ................................................................. 19

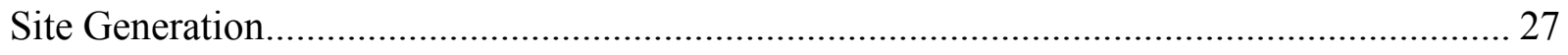

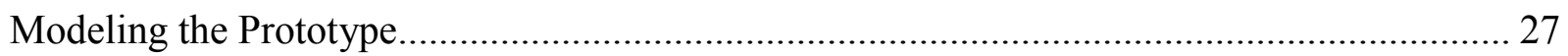

Operating Conditions ............................................................................. 28

Reporting Energy Use and Energy Savings.................................................. 32

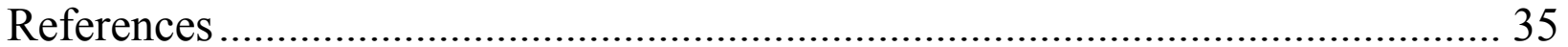




\section{Definitions}

A/C

ACCA

$\mathrm{ACH}$

AFUE

ASHRAE

ASTM

BA

CEC

CFA

$\mathrm{cfm}$

DHW

DOE

DSE

DUF

EER

ELA

ELCAP

EPA

FFA

FHA

FSEC

HERS

HP

HUD

ICC

IECC

LBNL

MAT

MEC

MEL

NAECA

NASEO air conditioning

Air Conditioning Contractors of America

air changes per hour

Annual Fuel Utilization Efficiency

American Society of Heating, Refrigerating \& Air

Conditioning Engineers

American Society for Testing and Materials

Building America

California Energy Commission

Conditioned Floor Area

cubic feet per minute

domestic hot water

U. S. Department of Energy

distribution system efficiency

dryer usage factor

energy efficiency ratio

Effective Leakage Area

End-Use Load and Consumer Assessment Program

U.S. Environmental Protection Agency

finished floor area

Federal Housing Administration

Florida Solar Energy Center

Home Energy Rating System

heat pump

U.S. Department of Housing and Urban Development

International Code Council

International Energy Conservation Code

Lawrence Berkeley National Laboratory

monthly average temperatures

Model Energy Code

miscellaneous electric loads

National Appliance Energy Conservation Act

National Association of State Energy Officials 
NREL

RECS

RESNET

SCE

SDT

SEER

SLA

TMY2

TPU

TRNSYS

UA

WDT
National Renewable Energy Laboratory

Residential Energy Consumption Study

Residential Energy Services Network

Southern California Edison Company

summer design temperatures

seasonal energy efficiency ratio

Specific Leakage Area

Typical Meteorological Year, Version 2

Tacoma Public Utilities

TRaNsient SYstem Simulation Program

heat loss coefficient

winter design temperature 


\section{Introduction}

To track progress toward aggressive multi-year, whole-house energy savings goals of $40 \%-70 \%$ and onsite power production of up to 30\%, the U.S. Department of Energy (DOE) Residential Buildings Program and the National Renewable Energy Laboratory (NREL) developed the Building America Research Benchmark in consultation with the Building America industry teams. The Benchmark is generally consistent with mid-1990s standard practice, as reflected in the Home Energy Rating System (HERS) Technical Guidelines (RESNET 2002), with additional definitions that allow the analyst to evaluate all residential end-uses, an extension of the traditional HERS rating approach that focuses on space conditioning and hot water. Unlike the reference homes used for HERS, Energy Star, and most energy codes, the Benchmark represents typical construction at a fixed point in time so it can be used as the basis for Building America's multi-year energy savings goals without the complication of chasing a "moving target". As time passes, we expect energy codes to become more and more energy efficient compared to the Benchmark as better construction practices and more efficient equipment become commonplace in the market. A series of user profiles, intended to represent the behavior of a "standard" set of occupants, was created for use in conjunction with the Benchmark. The Benchmark is only intended for use with detached and attached single-family housing. It is not suitable for multi-family housing as written.

\section{Benchmark House Specifications}

The following sections summarize the definition of the Benchmark, updated for the FY07 Building America subcontracts. A comprehensive description of other important Building America reference houses (Builder Standard Practice and Regional Standard Practice), along with guidance for using hourly simulation tools to compare an energy-efficient prototype house to the various base-case houses, can be found in the NREL technical report addressing systems-based performance analysis of residential buildings (Hendron et al 2004). NREL and other Building America partners have also developed a series of tools, including spreadsheets with detailed hourly energy usage and load profiles, to help analysts apply the Benchmark quickly and in a consistent manner. These tools can be found on the Building America Web site (http://www.eere.energy.gov/buildings/building_america/pa_resources.html).

Any element of the Benchmark definition that is not specifically addressed in the following sections is assumed to be the same as the Prototype house. Because the definition is intended to be software-neutral, certain elements of the Benchmark cannot be modeled directly using every common simulation tool. If the energy use associated with such elements is significant, then they should be modeled or handcalculated separately from the building model and reasonable adjustments should be made to the wholehouse simulation results. If there is no significant energy effect associated with these elements, the Prototype and Benchmark should be modeled using similar approximations in an energy-neutral manner. The full Building America Performance Analysis Procedures (Hendron et al 2004) include application notes addressing some practical implementation issues that may be encountered when simulating the Benchmark using DOE-2.2 or EnergyGauge. 


\section{Building Envelope}

All building envelope components (including walls, windows, foundation, roof, and floors) for the Benchmark shall be consistent with the HERS Reference Home as defined by the National Association of State Energy Officials (NASEO) and the Residential Energy Services Network (RESNET) in the "National Home Energy Rating Technical Guidelines," dated September 19, 1999 (RESNET 2002). These requirements are summarized below, along with a few minor clarifications and additional requirements. References to U-values in the 1993 Model Energy Code have been updated to 2003 International Energy Conservation Code (IECC), because the corresponding U-values are identical and the IECC is more readily available (ICC 2003).

The Benchmark envelope specifications are as follows:

- The same shape and size as the Prototype

- The same area of surfaces bounding conditioned space as the Prototype with the exception of the attic, which shall be insulated at the attic floor and have a ventilation area of $1 \mathrm{ft}^{2}$ per $300 \mathrm{ft}^{2}$ ceiling area, regardless of the Prototype attic design

- The same foundation type (slab, crawl space, or basement) as the Prototype

- The same basement wall construction type as the Prototype (e.g., masonry, wood frame, other)

- No sunrooms

- No horizontal fenestration, defined as skylights, or light pipes oriented less than 45 degrees from a horizontal plane

- Window area $\left(\mathrm{A}_{\mathrm{F}}\right)$, including framing, determined by Equation 1 for detached homes and by Equation 2 for attached homes

Equation 1: $\quad A_{F}=0.18 \times A_{F L} \times F_{A}$,

Equation 2: $\quad A_{F}=0.18 \times A_{F L} \times F_{A} \times F$

where

$$
\begin{aligned}
\mathrm{A}_{\mathrm{F}} & =\text { total window area }\left(\mathrm{ft}^{2}\right) \\
\mathrm{A}_{\mathrm{FL}} & =\text { total floor area, including basement }\left(\mathrm{ft}^{2}\right) \\
\mathrm{F}_{\mathrm{A}}= & (\text { exposed thermal boundary wall area }) /(\text { total thermal boundary wall area }) . \\
\mathrm{F} & =(\text { total thermal boundary wall area }) /(\text { total thermal boundary wall area }+ \\
& \text { common wall area }), \text { or } 0.56, \text { whichever is greater, }
\end{aligned}
$$

and where

total thermal boundary wall is any wall that separates directly or indirectly conditioned space from unconditioned space or ambient conditions, including all insulated basement walls but not including unvented crawl space walls;

exposed thermal boundary wall is any thermal boundary wall not in contact with soil; and

common wall area is the total area of walls adjacent to another conditioned living unit, including basement and directly or indirectly conditioned crawl space walls.

- The window area calculated above is distributed with the same proportion on each wall and on each floor as the Prototype house. Thirty-three percent of the window area on each facade is can be opened for the purpose of natural ventilation. The energy use is calculated with the Benchmark house in each of four orientations rotated in $90^{\circ}$ increments relative to the Prototype orientation $\left(+0^{\circ},+90^{\circ},+180^{\circ},+270^{\circ}\right)$, and the average of these four cases is used to represent the energy use of the Benchmark. 
- Thermal conductance of all thermal boundary elements equal to the requirements, expressed as $\mathrm{U}$ values, of Paragraph 502.2 of the 2003 IECC (ICC 2003), as summarized below. Unless otherwise specified, these U-values are for entire assemblies, including sheathing, framing, finishes, and so on.

- U-value $\left(U_{\mathrm{w}}\right)$ for the opaque fraction of exterior walls from Table 1 or 2 , as appropriate.

- The U-value and solar heat gain coefficient (SHGC) for vertical fenestration, including windows and sliding glass doors, shall be determined using Table 3. The values in Table 3 were calculated based on the HERS methodology for determining maximum window U-value, assuming a floor area to wall area ratio of 1.0. If the simulation tool uses a window library, a window that approximately matches the $U_{F}$ and SHGC shall be selected, and the frame R-value shall be increased or decreased until the overall window $\mathrm{U}_{\mathrm{F}}$ matches the value in Table 3 .

Table 1. Opaque Wall U-Values $\left(U_{w}\right)$ for Detached Homes (excerpted from ICC 2003)

\begin{tabular}{|c|c|}
\hline $\begin{array}{c}\text { Annual Heating Degree Days Base } \\
65 \text { (HDD65) from Nearest Location } \\
\text { Listed in Chapter } 9 \text { of ASHRAE } \\
\text { Standard } 90.2 \text { or NREL's Solar } \\
\text { Radiation Data Manual }{ }^{1} \\
\end{array}$ & 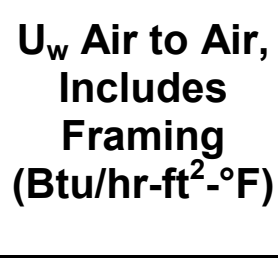 \\
\hline$>13,000$ & 0.038 \\
\hline $9,000-12,999$ & 0.046 \\
\hline $6,500-8,999$ & 0.052 \\
\hline $4,500-6,499$ & 0.058 \\
\hline $3,500-4,499$ & 0.064 \\
\hline $2,600-3,499$ & 0.076 \\
\hline$<2,600$ & 0.085 \\
\hline
\end{tabular}

Table 2. Opaque Wall U-values $\left(U_{w}\right)$ for Attached Homes (excerpted from ICC 2003)

\begin{tabular}{|c|c||}
\hline $\begin{array}{c}\text { Heating Degree Days Base 65 } \\
\text { (HDD65) from Nearest Location } \\
\text { Listed in Chapter 9 of ASHRAE } \\
\text { Standard 90.2, or NREL's Solar } \\
\text { Radiation Data Manual }\end{array}$ & $\begin{array}{c}\mathrm{U}_{\mathrm{w}} \text { Air to Air, } \\
\text { Includes } \\
\text { Framing } \\
\text { (Btu/hr-ft }{ }^{2}{ }^{\circ} \mathrm{F} \text { ) }\end{array}$ \\
\hline$>9,000$ & 0.064 \\
\hline $7,100-8,999$ & 0.076 \\
\hline $3,000-7,099$ & 0.085 \\
\hline $2,800-2,999$ & 0.100 \\
\hline $2,600-2,799$ & 0.120 \\
\hline$<2,600$ & 0.140 \\
\hline
\end{tabular}

${ }^{1}$ See Solar Radiation Data Manual for Buildings (or the "Blue Book") published by the NREL (NREL 1995) (http://rredc.nrel.gov/solar/old_data/nsrdb/bluebook/). 
Table 3. Vertical Fenestration U-values $\left(U_{F}\right)$ and SHGC

\begin{tabular}{|c|c|c|}
\hline $\begin{array}{c}\text { HDD65 from Nearest Location } \\
\text { Listed in Chapter 9 of ASHRAE } \\
\text { Standard 90.2, or NREL's Solar } \\
\text { Radiation Data Manual }\end{array}$ & $\begin{array}{c}\text { UF Air to Air, } \\
\text { Includes Framing } \\
\text { and Sash } \\
\text { (Btu/hr-ft'- }{ }^{\circ} \text { F) }\end{array}$ & $\begin{array}{c}\text { SHGC, } \\
\text { Includes } \\
\text { Framing and } \\
\text { Sash }\end{array}$ \\
\hline$\geq 7,000$ & 0.36 & 0.32 \\
\hline $6,000-6,999$ & 0.39 & 0.32 \\
\hline $5,000-5,999$ & 0.46 & 0.58 \\
\hline $4,000-4,999$ & 0.53 & 0.58 \\
\hline $3,000-3,999$ & 0.58 & 0.58 \\
\hline $2,000-2,999$ & 0.62 & 0.65 \\
\hline $1,000-1,999$ & 0.79 & 0.65 \\
\hline$\leq 999$ & 1.00 & 0.79 \\
\hline
\end{tabular}

- U-value of an insulated floor above a vented crawl space or other unconditioned space shall be as specified in Figure 1 (excerpted from ICC 2003).

$\circ \quad$ U-value of insulated walls in an unvented crawl space shall be as specified in Figure 2 (excerpted from ICC 2003). This U-value represents the combined effect of wall components and the surface air film, but it does not include adjacent soil.

- U-value of insulated basement walls shall be as specified in Figure 3 (excerpted from ICC 2003), and the insulation shall be located on the interior surface of the walls. This U-value represents the basement wall assembly, including the surface air film, but it does not include ground effects.

- R-value and depth of slab edge insulation for slab-on-grade construction shall be as specified in Figure 4 (excerpted from ICC 2003). This R-value is for rigid foam insulation and does not include the slab itself or ground effects.

- U-value of insulated roof/ceiling shall be as specified in Figure 5 (excerpted from ICC 2003). If the Prototype includes an attic, the Benchmark shall have an unconditioned attic with insulation at the attic floor. 


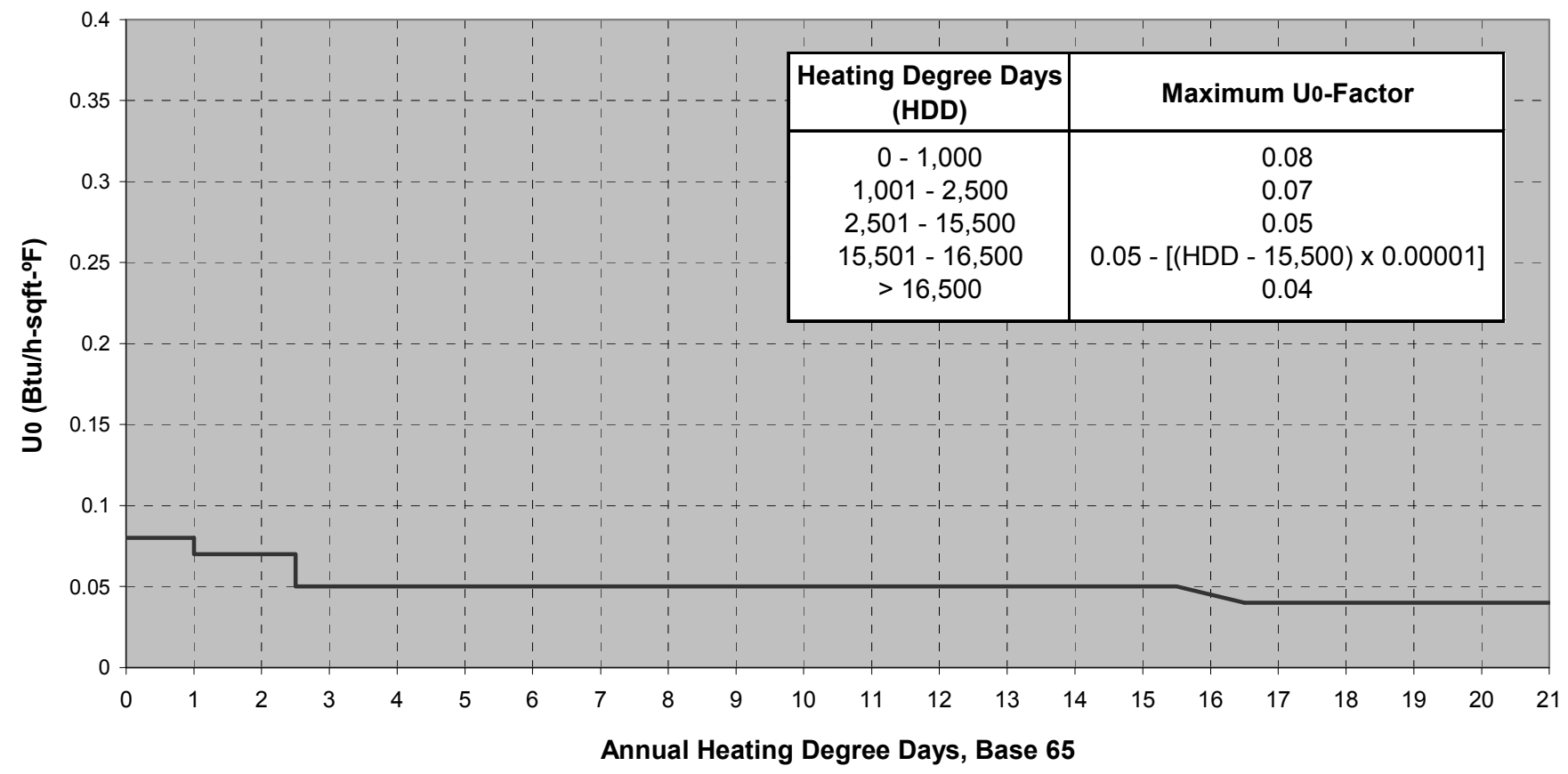

Figure 1. U-value of floor over unconditioned space (Excerpted from ICC 2003)

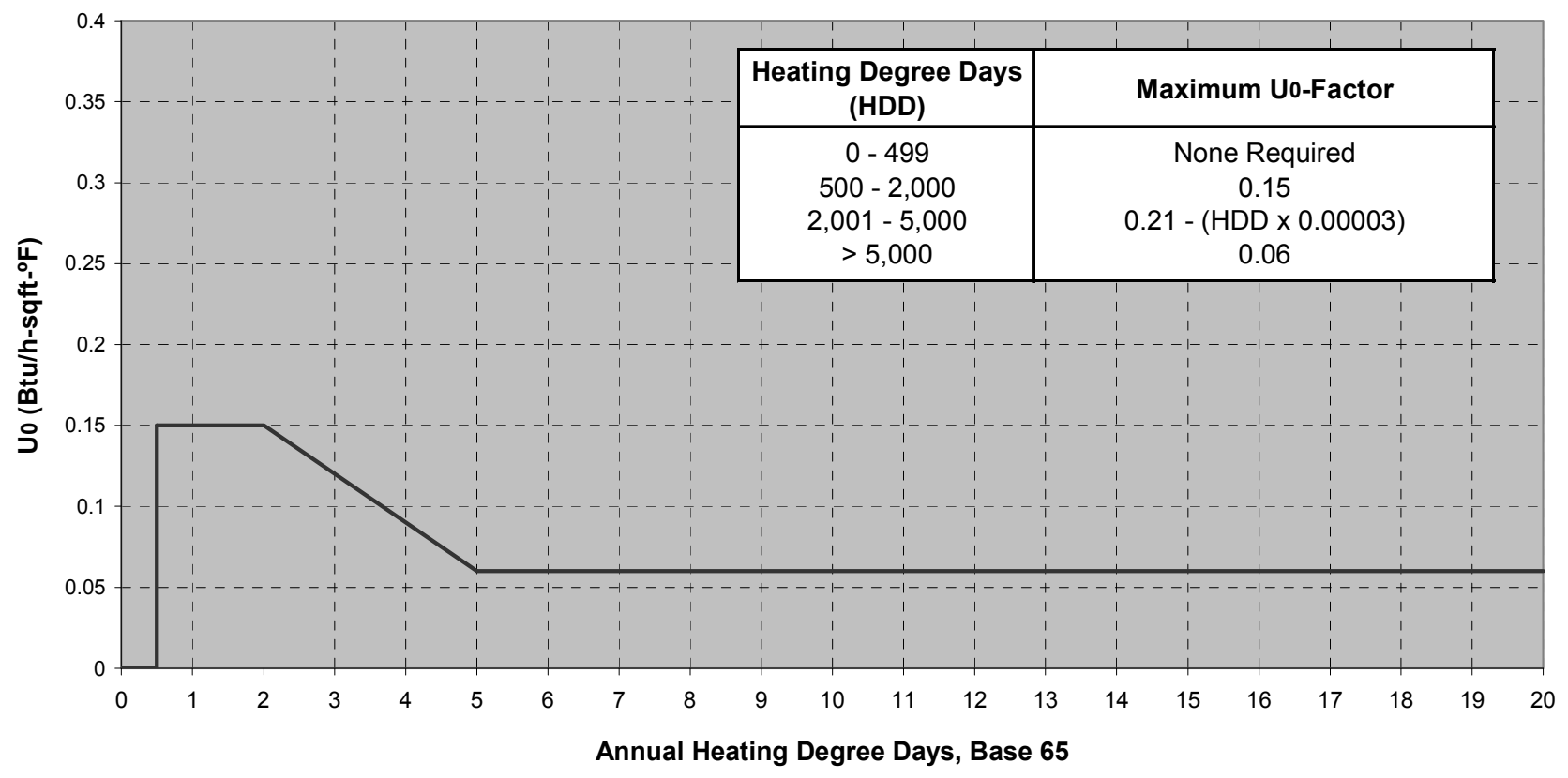

Figure 2. Unvented crawl space wall U-value (Excerpted from ICC 2003) 


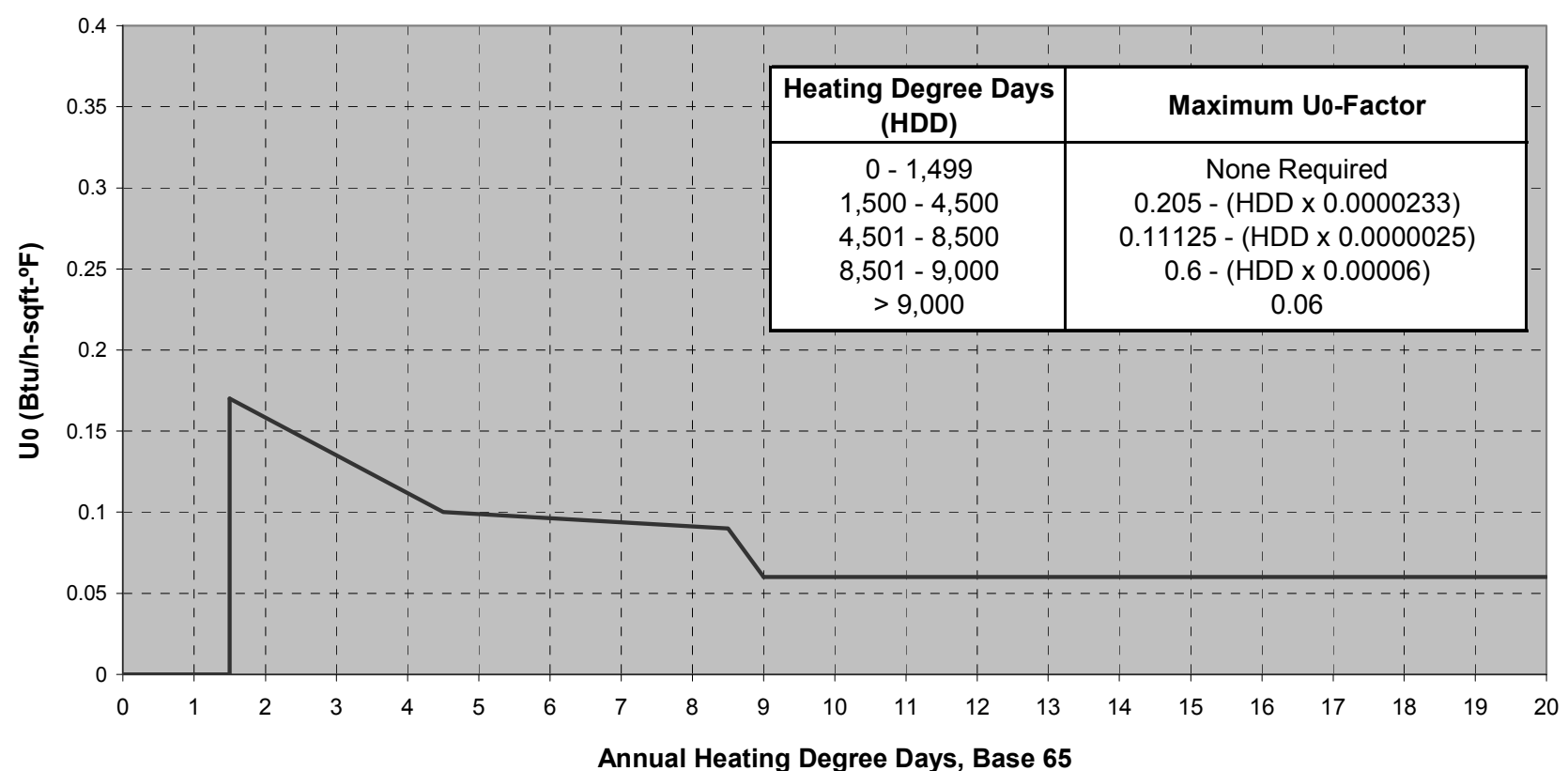

Figure 3. Basement wall U-value (Excerpted from ICC 2003)

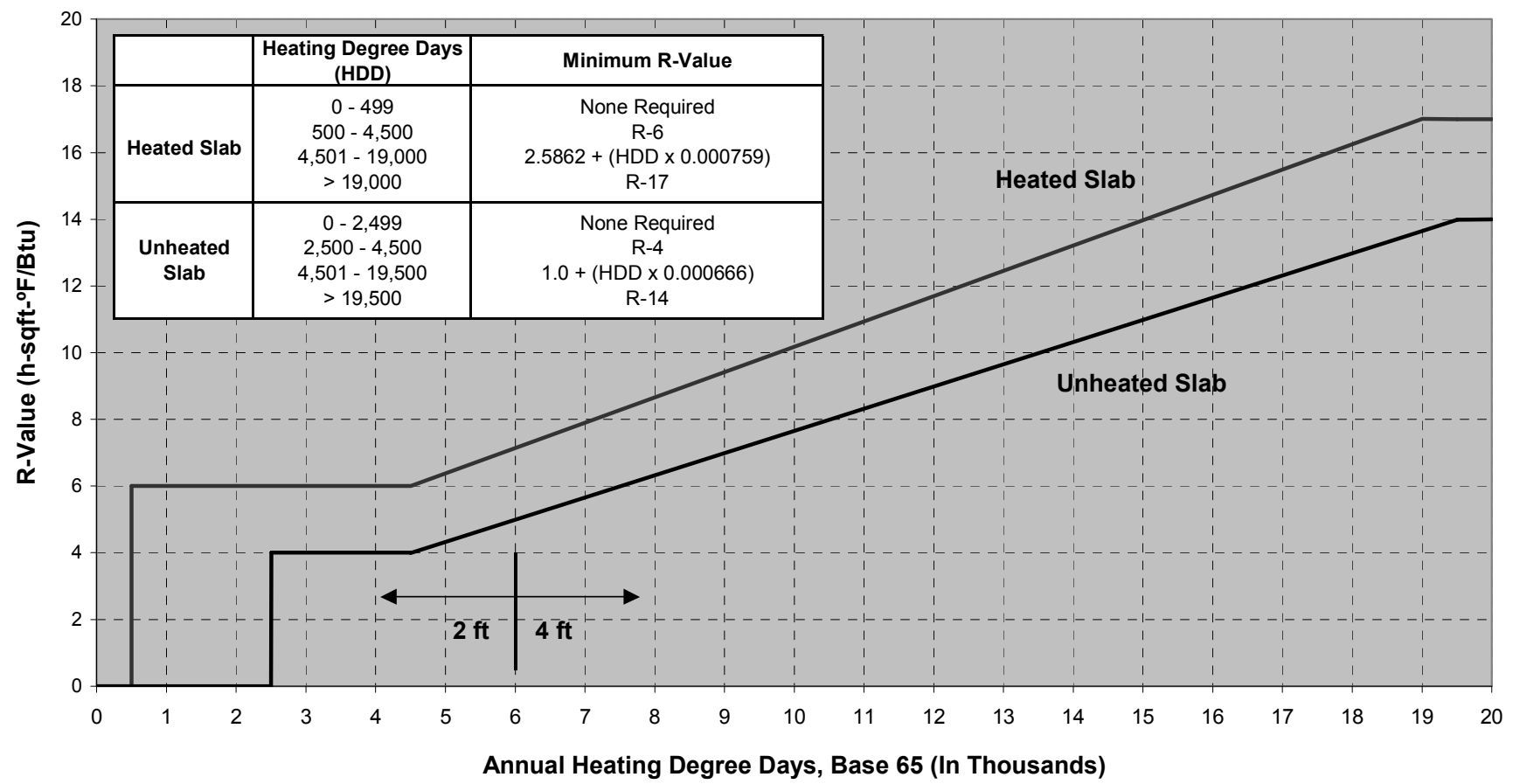

Figure 4. Slab insulation R-value and depth (Excerpted from ICC 2003) 


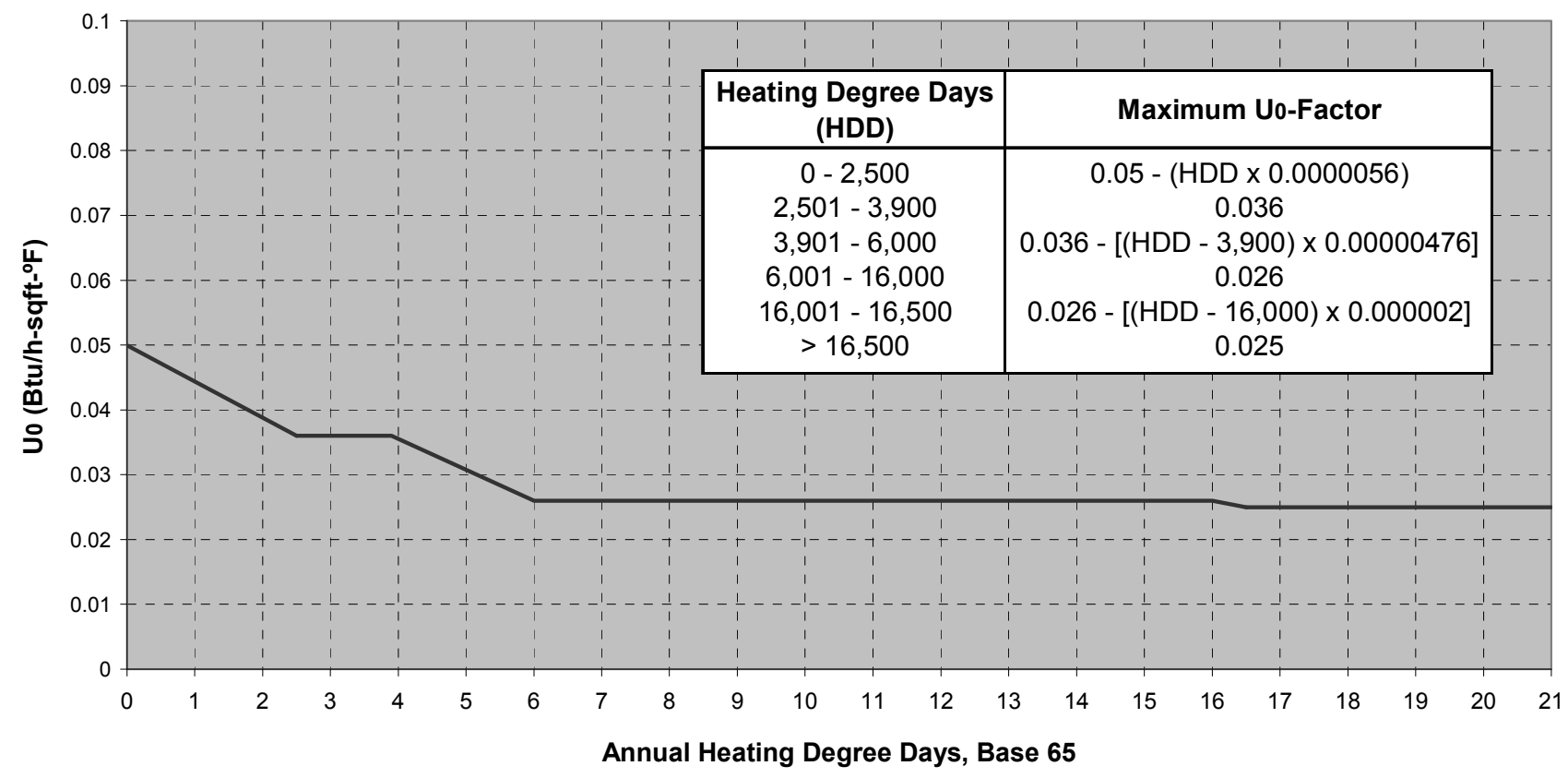

Figure 5. Roof/ceiling assembly U-value (Excerpted from ICC 2003)

- No external shading at any time from roof projections, awnings, adjacent buildings, trees, etc. Basic architectural features such as attached garages and enclosed porches shall be included in the Benchmark model, but the model shall not include window shading effects from these features.

- No self-shading shall be modeled for the Benchmark.

- Total area of opaque exterior doors is equal to $40 \mathrm{ft}^{2}$, facing north, with door U-value equal to $0.20 \mathrm{Btu} / \mathrm{hr} \cdot \mathrm{ft}^{2} \cdot{ }^{\circ} \mathrm{F}$ (air-to-air).

- Solar absorptivity is equal to 0.50 for opaque areas of exterior walls, and 0.75 for opaque areas of roofs.

- Total emittance of exterior walls and roofs is equal to 0.90 .

- The above-grade exterior walls shall be light-frame $2 \times 4$ or $2 \times 6$ wood construction with sufficient insulation to achieve the correct overall $\mathrm{U}$-value. The framing factors in Table 4 are representative of typical construction practices, and shall be used as inputs for the Benchmark model.

Table 4. Benchmark Framing Factors

\begin{tabular}{|c|c|c|}
\hline $\begin{array}{c}\text { Enclosure } \\
\text { Element }\end{array}$ & $\begin{array}{c}\text { Frame } \\
\text { Spacing } \\
\text { (inches o.c.) }\end{array}$ & $\begin{array}{c}\text { Framing } \\
\text { Fraction } \\
\text { (\% area) }\end{array}$ \\
\hline Walls & 16 & $23 \%$ \\
\hline Floors & 16 & $13 \%$ \\
\hline $\begin{array}{c}\text { Ceilings Below } \\
\text { Unconditioned Space }\end{array}$ & 24 & $11 \%$ \\
\hline
\end{tabular}

- Interior partition walls shall be light-frame $(2 \times 4)$ wood construction.

- Masonry basement floor slabs and slab-on-grade foundations shall have $80 \%$ of floor area covered by R-2 carpet and pad and $20 \%$ of floor area directly exposed to room air. 


\section{Space Conditioning/Air Distribution Equipment}

Space conditioning equipment type and efficiency for the Building America Benchmark shall meet the following requirements:

- The equipment type and efficiency for the Benchmark shall be based on the type of heating and air-conditioning equipment found in the Prototype, as shown in Table 5.

- If the simulation tool requires the use of Energy Efficiency Ratio (EER) instead of Seasonal Energy Efficiency Ratio (SEER) for a heat pump or air conditioner, then the EER for the Benchmark shall be calculated using Equation 3. If the actual EER for the Prototype is not readily available, Equation 3 may also be used to make an approximate conversion from SEER to EER (Wassmer 2003):

\section{Equation 3: $\quad$ EER $=-0.02 \times$ SEER $^{2}+1.12 \times$ SEER}

- Heating and cooling equipment (including the air handler) shall be sized using the procedures published by the Air Conditioning Contractors of America (ACCA). (See www.accaconference.com/Merchant $2 /$ merchant.mv?Screen $=$ CTGY\&Store Code $=$ ACCOA\&Cat egory Code $=$ M.)

- The Benchmark shall not have a whole-house fan.

- If the Prototype actively controls relative humidity, then the Benchmark shall include a standalone dehumidifier with an energy factor of 1.1 liters $/ \mathrm{kWh}$ (EPA 2006). Sensible heat generated by the dehumidifier shall be added to the cooling load.

- The Benchmark air handler shall have power consumption equal to $0.00055 \mathrm{~kW} / \mathrm{cfm}$.

The Benchmark shall include an air distribution system with the properties listed in Table 6 . The location of the ductwork in the Benchmark is based on the type of foundation used for the Prototype. If the simulation tool does not permit the input of duct specifications to this level of detail, then two values (one for heating, one for cooling) of seasonal distribution system efficiency (DSE) shall be estimated and applied to the heating and cooling system efficiencies to represent typical losses from ducts. The DSE values shall be determined using Table 6 and the procedures in the Draft ASHRAE Standard 152P (ASHRAE 2001). A spreadsheet developed by Lawrence Berkeley National Laboratory (LBNL) and modified by NREL is posted on the Building America Web site to assist with this calculation.

Table 5. Benchmark Space Conditioning Equipment Efficiencies

\begin{tabular}{|c|c|c|}
\hline Prototype Equipment & Function & Benchmark Space Conditioning Device \\
\hline Gas or Oil Fired Furnace & Heating & $78 \%$ AFUE Gas Furnace \\
\hline Mobile Home Furnace & Heating & $75 \%$ AFUE Gas Furnace \\
\hline Gas or Oil Fired Boiler (Except Gas Steam) & Heating & $80 \%$ AFUE Gas Boiler \\
\hline Gas Steam Boiler & Heating & $75 \%$ AFUE Gas Steam Boiler \\
\hline Gas Space Heater & Heating & $74 \%$ AFUE Gas Space Heater \\
\hline Other Non-Electric Boiler & Heating & $80 \%$ AFUE Gas Boiler \\
\hline Other Non-Electric Heating & Heating & $78 \%$ AFUE Gas Furnace \\
\hline Electric or No System & Heating & 6.8 HSPF Air Source Heat Pump \\
\hline Air Source Heat Pump (Split) & Heating/Cooling & 6.8 HSPF Air Source Heat Pump \\
\hline Air Source Heat Pump (Package) & Heating/Cooling & 6.6 HSPF Air Source Heat Pump \\
\hline
\end{tabular}




\begin{tabular}{|c|c|c|}
\hline Prototype Equipment & Function & Benchmark Space Conditioning Device \\
\hline Split System Air Conditioner & Cooling & 10 SEER Air Conditioner \\
\hline Single Package Air Conditioner & Cooling & 9.7 SEER Air Conditioner \\
\hline Room Air Conditioner & Cooling & 9.0 EER Room Air Conditioner \\
\hline Other Type or No Air Conditioner & Cooling & 10 SEER Air Conditioner \\
\hline
\end{tabular}

Table 6. Duct Locations and Specifications for the Benchmark

\begin{tabular}{|c|c|c|c|}
\hline & \multirow{2}{*}{$\begin{array}{c}\text { Prototype } \\
\text { Foundation Type }\end{array}$} & \multicolumn{2}{|c|}{ Benchmark Duct Specification } \\
\hline & & One-Story & Two-Story or Higher \\
\hline Supply Duct Surface Area $\left(\mathrm{ft}^{2}\right)$ & All & $0.27 \times \mathrm{FFA}^{\mathrm{a}}$ & $0.20 \times \mathrm{FFA}$ \\
\hline Return Duct Surface Area $\left(\mathrm{ft}^{2}\right)$ & All & $\begin{array}{c}0.05 \times \mathrm{N}_{\text {returns }} \times \mathrm{FFA} \\
\text { (Maximum of } 0.25 \times \mathrm{FFA})\end{array}$ & $\begin{array}{c}0.04 \times \mathrm{N}_{\text {returns }} \times \mathrm{FFA} \\
\text { (Maximum of } 0.19 \times \mathrm{FFA} \text { ) }\end{array}$ \\
\hline $\begin{array}{l}\text { Supply Duct Insulation } \\
\text { (Conditioned Space) }\end{array}$ & All & \multicolumn{2}{|c|}{ R-3.3 } \\
\hline $\begin{array}{l}\text { Return Duct Insulation } \\
\text { (Conditioned Space) }\end{array}$ & All & \multicolumn{2}{|c|}{ None } \\
\hline $\begin{array}{l}\text { Supply/Return Duct Insulation } \\
\text { (Unconditioned Space) }\end{array}$ & All & \multicolumn{2}{|c|}{ R-5.0 } \\
\hline Duct Material & All & \multicolumn{2}{|c|}{ Sheet Metal } \\
\hline $\begin{array}{l}\text { Duct Leakage } \\
\text { (Inside + Outside) }\end{array}$ & All & \multicolumn{2}{|c|}{$\begin{array}{c}15 \% \text { of Air Handler Flow ( } 7 \% \text { Supply, } 3 \% \text { Return, } 5 \% \text { Air Handler) } \\
\text { (Percentage lost to each space equal to percentage of duct area in that } \\
\text { space, as specified below. } 50 \% \text { of flow imbalances between an } \\
\text { unconditioned basement and living space shall be made up by outside } \\
\text { air, with the rest caused by direct air movement between the basement } \\
\text { and living space.) }\end{array}$} \\
\hline \multirow{3}{*}{ Supply Duct Location } & $\begin{array}{l}\text { Slab-on-grade or } \\
\text { Raised floor }\end{array}$ & $100 \%$ Attic $^{b}$ & $65 \%$ Attic $^{\mathrm{b}}, 35 \%$ Conditioned Space \\
\hline & Crawl space & $100 \%$ Crawl space & $\begin{array}{l}\text { 65\% Crawl space, } 35 \% \text { Conditioned } \\
\text { Space }\end{array}$ \\
\hline & Basement & $100 \%$ Basement & $\begin{array}{c}65 \% \text { Basement, } 35 \% \text { Conditioned } \\
\text { Space }\end{array}$ \\
\hline \multirow{3}{*}{$\begin{array}{l}\text { Return Duct and Air Handler } \\
\text { Location }\end{array}$} & $\begin{array}{c}\text { Slab-on-grade or } \\
\text { Raised floor }\end{array}$ & $100 \%$ Attic $^{b}$ & $100 \%$ Attic $^{\mathrm{b}}$ \\
\hline & Crawl space & $100 \%$ Crawl space & $100 \%$ Crawl space \\
\hline & Basement & $100 \%$ Basement & $100 \%$ Basement \\
\hline
\end{tabular}

${ }^{a}$ Finished floor area $\left(\mathrm{ft}^{2}\right)$

${ }^{b}$ If the Prototype does not have an attic, then this percentage of duct leakage in the Benchmark is assumed to be in an attached garage. If the Prototype does not have an attached garage, then the leakage is assumed to be in conditioned space.

\section{Domestic Hot Water}

The assumptions in Tables 7 and 8 shall be made for the domestic hot-water system in the Benchmark. Both storage and burner capacity are determined using the guidelines recommended by ASHRAE in the HVAC Applications Handbook (ASHRAE 1999); these are based on the minimum capacity permitted by the Department of Housing and Urban Development (HUD) and the Federal Housing Administrations (FHA) (HUD 1982). Energy factor is the NAECA minimum for the corresponding fuel type and storage capacity (DOE 2002a). An example set of DHW specifications based on a typical three-bedroom, twobathroom Prototype is shown in Table 9. The "Appliance and DHW" spreadsheet developed by NREL 
automates many of the equations discussed in the following paragraphs and can be downloaded from the Building America Web site (http://www.eere.energy.gov/buildings/building_america/pa_resources.html).

Table 7. Characteristics of Benchmark Domestic Hot-Water System

\begin{tabular}{|l|c|c|}
\hline \multirow{2}{*}{} & \multicolumn{2}{|c|}{ Water Heater Fuel Type in Prototype } \\
\cline { 2 - 3 } & Electric & Gas \\
\hline Storage Capacity (V) (Gallons) & See Table 8 & See Table 8 \\
\hline Energy Factor (EF) & $0.93-(0.00132 \times \mathrm{V})$ & $0.62-(0.0019 \times \mathrm{V})$ \\
\hline Recovery Efficiency (RE) & 0.98 & 0.76 \\
\hline Burner Capacity & See Table 8 & See Table 8 \\
\hline Hot-water Set-Point & \multicolumn{2}{|c|}{$120^{\circ} \mathrm{F}$} \\
\hline Fuel Type & \multicolumn{2}{|c|}{ Same as Prototype } \\
\hline Tank Location & \multicolumn{2}{|c|}{ Same as Prototype } \\
\hline
\end{tabular}

a If the Prototype does not have a DHW system, or the hot-water system uses solar energy or a fuel other than gas or electricity, the Benchmark shall use the same fuel for water heating as that used for space heating.

Table 8. Benchmark DHW Storage and Burner Capacity (ASHRAE 1999)

\begin{tabular}{|c|c|c|c|c|c|c|c|c|c|c|c|c|}
\hline \multirow{3}{*}{$\begin{array}{l}\text { \# Bedrooms } \\
\text { \# Bathrooms } \\
\end{array}$} & \multirow{2}{*}{$\frac{1}{\text { All }}$} & \multicolumn{3}{|c|}{2} & \multicolumn{3}{|c|}{3} & \multicolumn{3}{|c|}{4} & \multirow{2}{*}{$\begin{array}{c}5 \\
\text { All }\end{array}$} & \multirow{2}{*}{$\begin{array}{r}6 \\
\text { All }\end{array}$} \\
\hline & & $\leq 1.5$ & $2-2.5$ & $\geq 3$ & $\leq 1.5$ & $2-2.5$ & $\geq 3$ & $\leq 1.5$ & $2-2.5$ & $\geq 3$ & & \\
\hline & & & & & & & & & & & & \\
\hline Storage (gal) & 20 & 30 & 30 & 40 & 30 & 40 & 40 & 40 & 40 & 50 & 50 & 50 \\
\hline Burner $(\mathrm{kBtu} / \mathrm{hr})$ & 27 & 36 & 36 & 36 & 36 & 36 & 38 & 36 & 38 & 38 & 47 & 50 \\
\hline Electric & & & & & & & & & & & & \\
\hline Storage (gal) & 20 & 30 & 40 & 50 & 40 & 50 & 50 & 50 & 50 & 66 & 66 & 80 \\
\hline Burner (kW) & 2.5 & 3.5 & 4.5 & 5.5 & 4.5 & 5.5 & 5.5 & 5.5 & 5.5 & 5.5 & 5.5 & 5.5 \\
\hline
\end{tabular}

Table 9. Example Characteristics of Benchmark Domestic Hot-Water System Based on a Prototype with Three Bedrooms and Two Bathrooms

\begin{tabular}{|l|c|c|}
\hline & \multicolumn{2}{|c|}{ Water Heater Fuel Type in Prototype } \\
\hline & Electric & Gas \\
\hline Storage Capacity (V) (Gallons) & 50 & 40 \\
\hline Energy Factor (EF) & 0.86 & 0.54 \\
\hline Recovery Efficiency (RE) & 0.98 & 0.76 \\
\hline Burner Capacity & $5.5 \mathrm{~kW}$ & $36,000 \mathrm{Btu} / \mathrm{hr}$ \\
\hline Supply Temperature & \multicolumn{2}{|c|}{$120^{\circ} \mathrm{F}$} \\
\hline Fuel Type & \multicolumn{2}{|c|}{ Same as Prototype } \\
\hline Tank Location & \multicolumn{2}{|c|}{ Same as Prototype } \\
\hline
\end{tabular}

NREL has also developed a spreadsheet that calculates the correct DHW inputs for the TRNSYS computer program, including standby heat loss coefficient (UA). The spreadsheet also has a comprehensive set of inputs and outputs that can be used to help calculate DHW properties for the Prototype house (Burch 2004). It can be found on the Building America Web site in the section for building scientists (http://www.eere.energy.gov/buildings/building_america/pa resources.html).

Four major end uses are identified for domestic hot water: showers, sinks, dishwasher, and clothes washer. The average daily water consumption by end use is shown in Table 10. For showers and sinks, the specified volume is the combined hot and cold water. This allows hot-water use to fluctuate 
depending on the cold water (mains) temperature. ${ }^{2}$ Hot-water usage for the clothes washer and dishwasher were estimated based on several scientific references studied by NREL. For showers and sinks, the water usage is based on the average of three domestic hot-water studies (Christensen, et. al. 2000, Burch and Salasovich 2002, and CEC 2002). The relationship between the number of bedrooms and hot-water usage was derived from the 1997 Residential Energy Consumption Study (RECS) (DOE 1999). This relationship also applies to machine energy for certain appliances, which will be discussed later in this report.

Table 10. Domestic Hot-water Consumption by End Use

\begin{tabular}{|c|c|c|c|}
\hline End Use & $\begin{array}{c}\text { End-Use } \\
\text { Water } \\
\text { Temperature }\end{array}$ & Water Usage & Latent Heat Gain \\
\hline Clothes Washer & $\mathrm{N} / \mathrm{A}$ & $\begin{array}{c}7.5+2.5 \times \mathrm{N}_{\mathrm{br}} \text { gal/day } \\
\text { (Hot Only) }\end{array}$ & $0^{*}$ \\
\hline Dishwasher & $\mathrm{N} / \mathrm{A}$ & $\begin{array}{c}2.5+0.833 \times \mathrm{N}_{\mathrm{br}} \text { gal/day } \\
\text { (Hot Only) }\end{array}$ & $0^{*}$ \\
\hline Shower & $105^{\circ} \mathrm{F}$ & $\begin{array}{c}14.0+4.67 \times \mathrm{N}_{\mathrm{br}} \text { gal/day } \\
(\text { Hot }+ \text { Cold })\end{array}$ & $\begin{array}{c}777+259 \times \mathrm{N}_{\mathrm{br}} \text { Btu/day } \\
\left(0.7+0.23 \times \mathrm{N}_{\mathrm{br}} \text { pints/day }\right)\end{array}$ \\
\hline Bath & $105^{\circ} \mathrm{F}$ & $\begin{array}{c}3.5+1.17 \times \mathrm{N}_{\mathrm{br}} \text { gal/day } \\
(\text { Hot }+ \text { Cold })\end{array}$ & $0^{* *}$ \\
\hline Sinks & $105^{\circ} \mathrm{F}$ & $\begin{array}{c}12.5+4.16 \times \mathrm{N}_{\mathrm{br}} \text { gal/day } \\
(\text { Hot }+ \text { Cold })\end{array}$ & $0^{* *}$ \\
\hline
\end{tabular}

* Latent heat gains from appliances are included in the section entitled "Appliances and Miscellaneous Electric Loads."

** Negligible compared to showers.

Hourly hot-water use profiles for individual hot-water end uses are shown in Figures 6-10. For software tools that do not accept this level of detail, the combined hourly hot-water profile may be used, as shown in Figure 11. The numerical values for normalized hourly hot-water use can be found in the Building America Analysis Spreadsheet.

This combined hourly profile is based on a 1990 study conducted by Becker and Stogsdill (Becker 1990), which included hot-water data from several earlier studies. The profiles for the clothes washer and dishwasher are based on the electrical end-use measurements in the ELCAP study conducted in the Pacific Northwest by the Bonneville Power Administration in the 1980s (Pratt et al 1989). It is assumed that the normalized hourly profiles for electricity and hot water are the same for these two appliances. The shower and sink profile was derived by subtracting the hourly clothes washer and dishwasher hotwater consumption from the combined hourly hot-water usage for a three-bedroom house in Memphis, Tennessee.

\footnotetext{
${ }^{2}$ The clothes washer in the Prototype may also consume a variable amount of hot water depending on mains temperature if it uses a thermostatic control valve to adjust the proportion of hot and cold water necessary to maintain a certain wash temperature. However, the Benchmark clothes washer does not have this feature.
} 


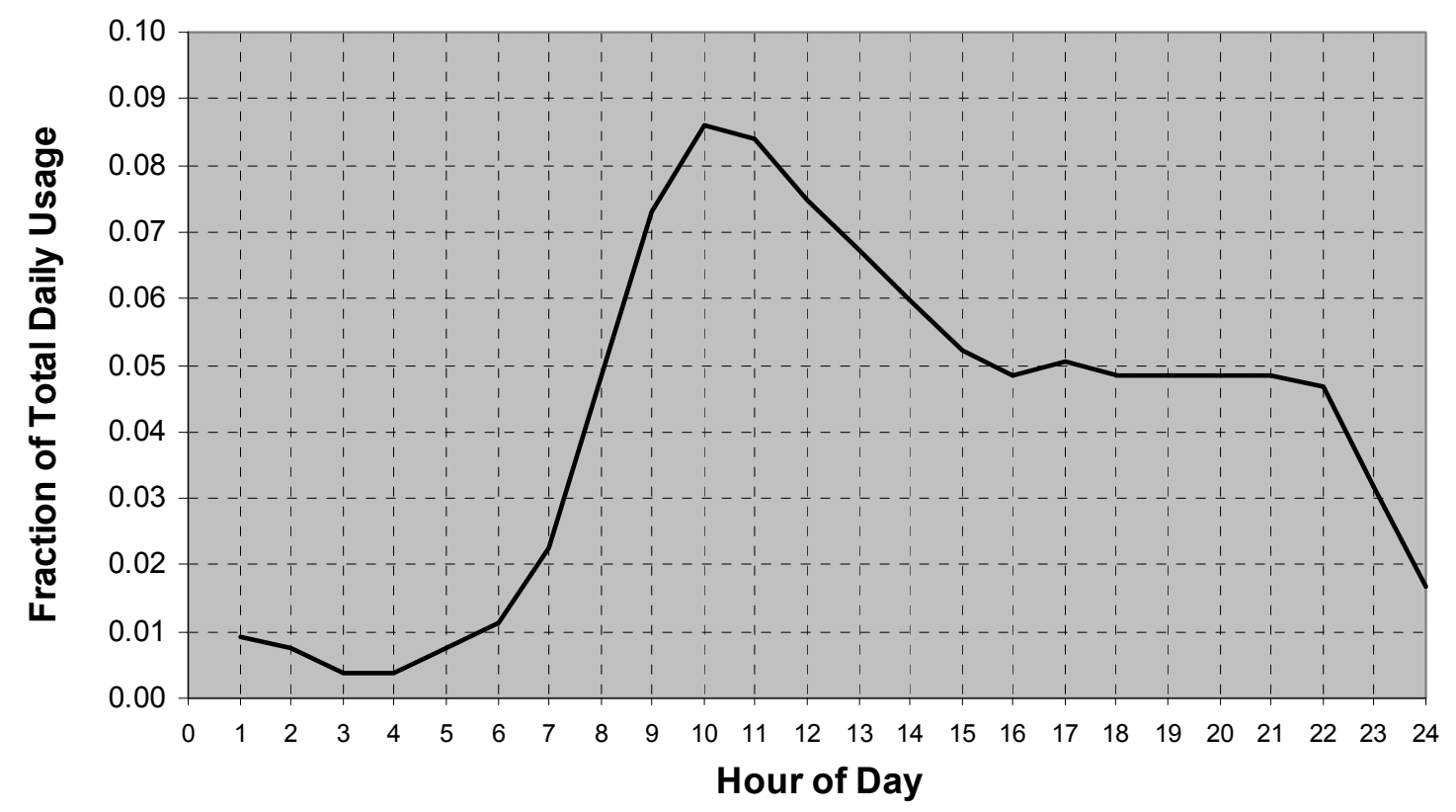

Figure 6. Clothes washer hot-water use profile

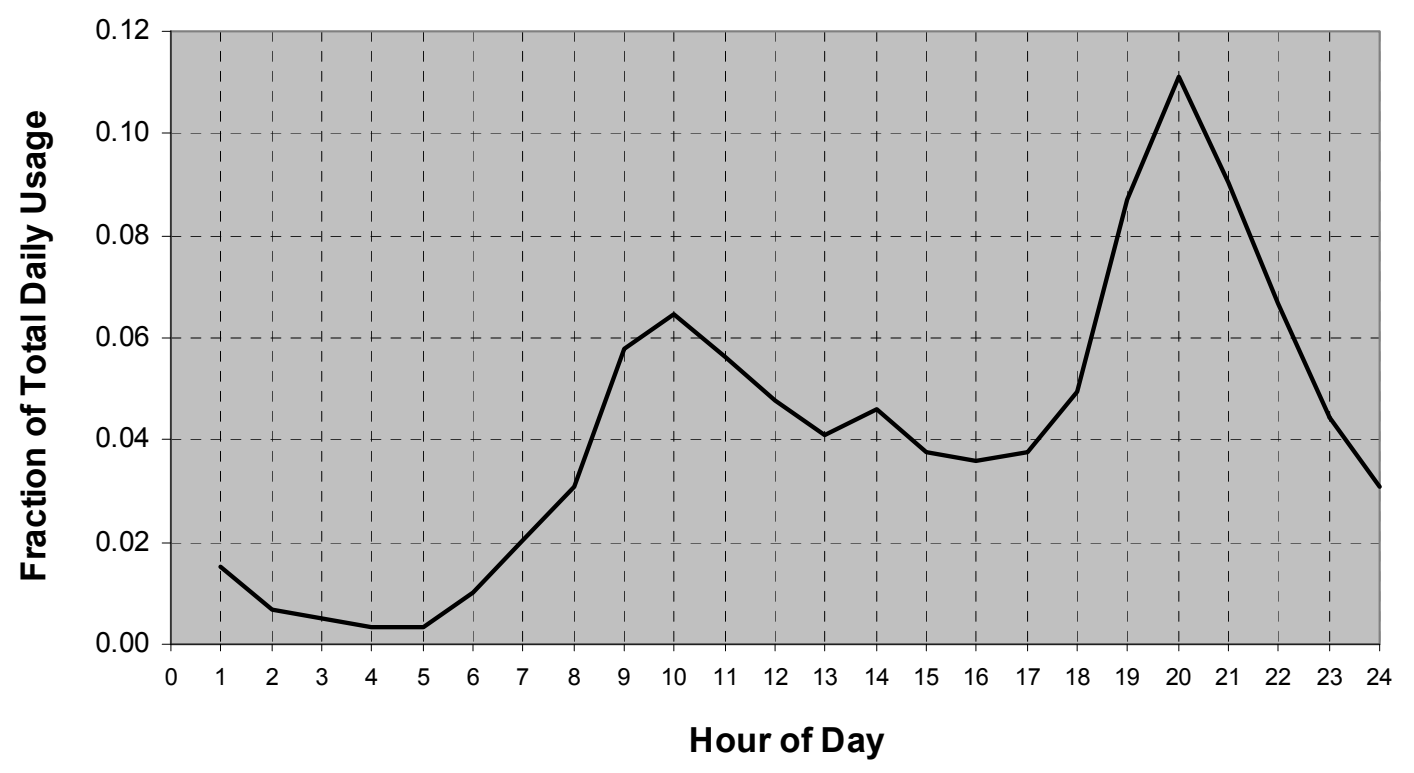

Figure 7. Dishwasher hot-water use profile 


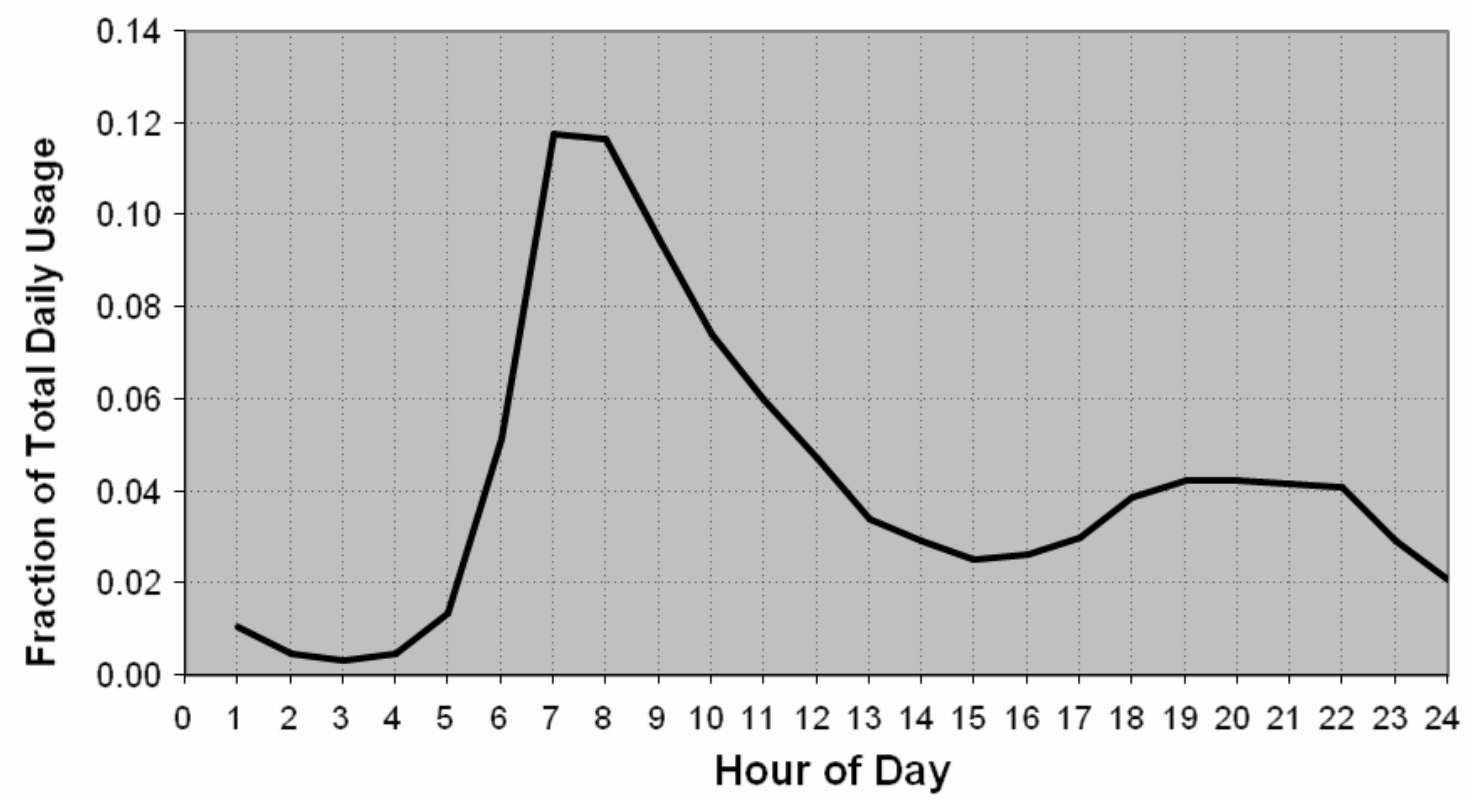

Figure 8. Shower hot-water use profile

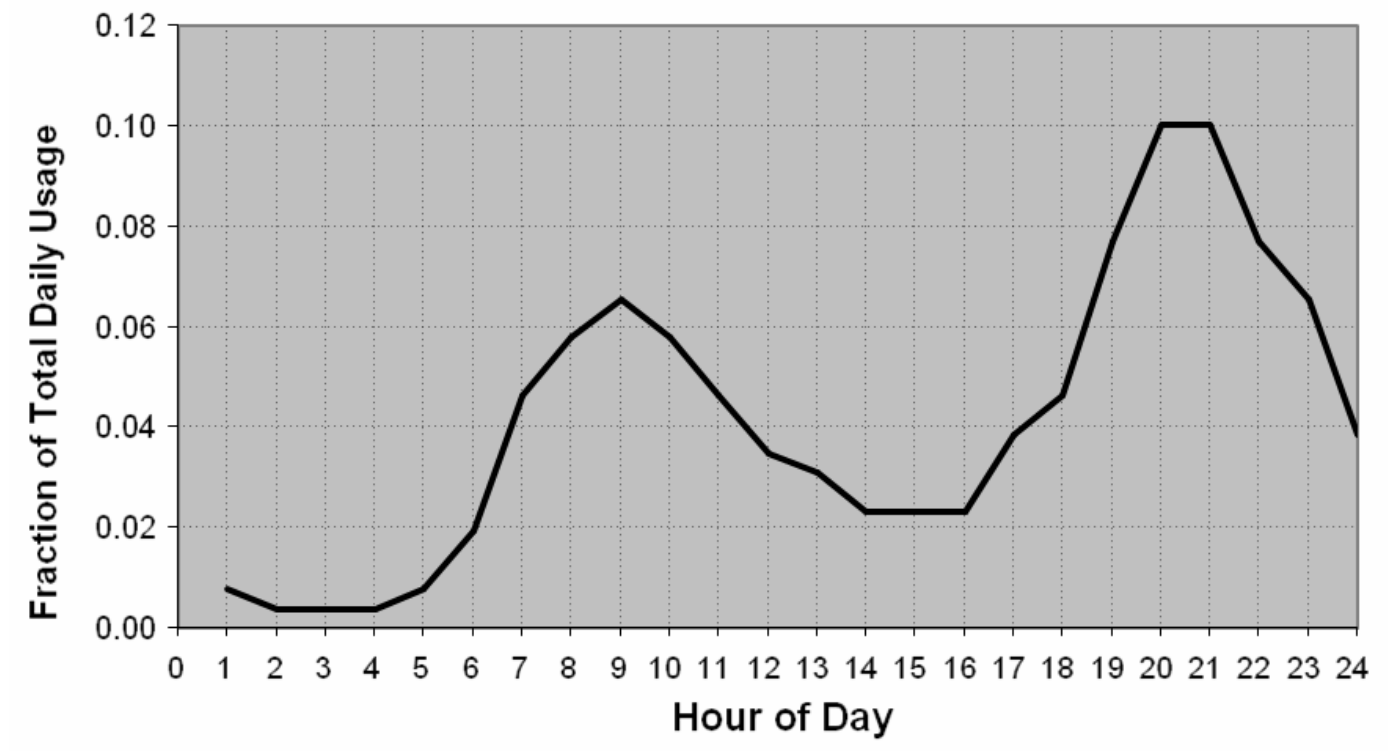

Figure 9. Bath hot-water use profile 


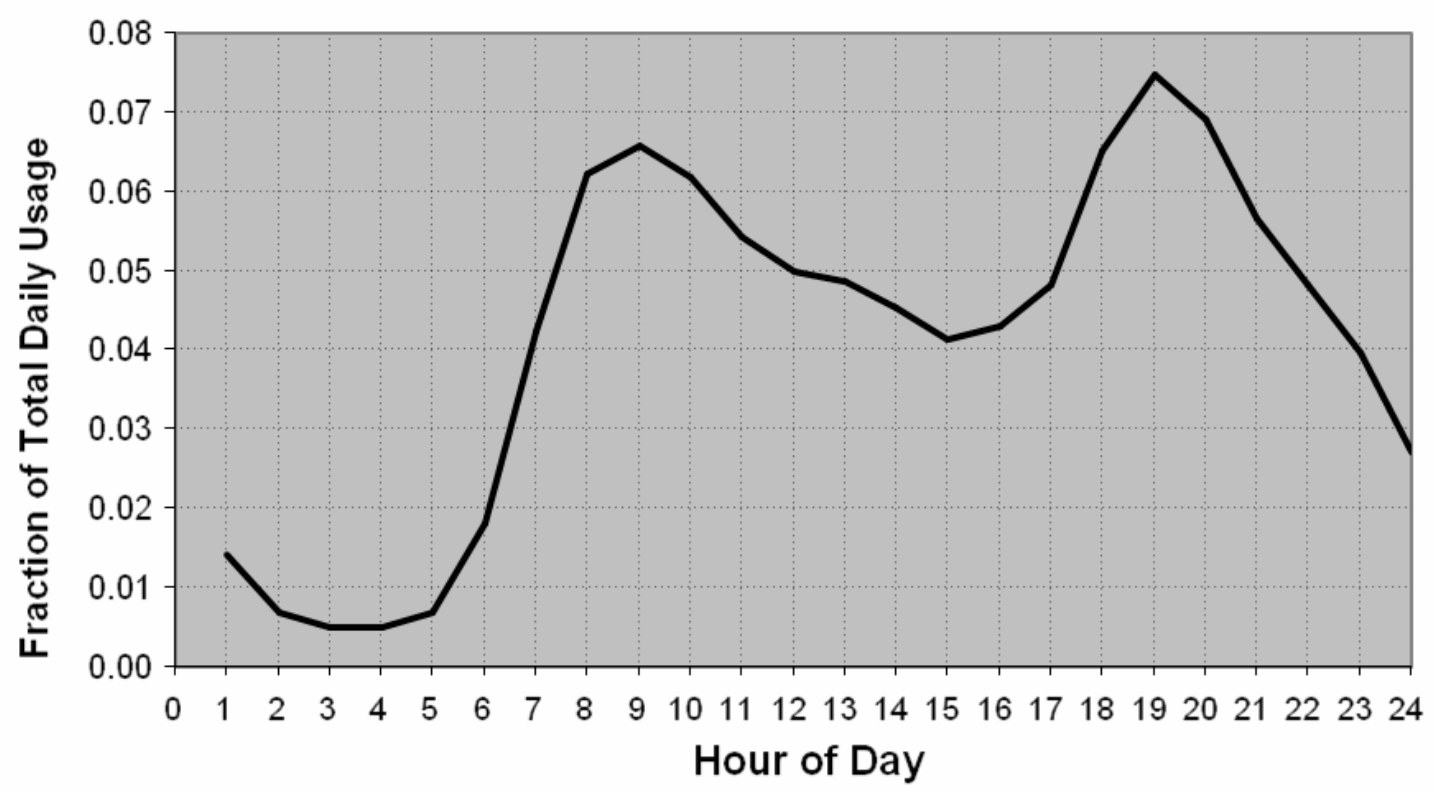

Figure 10. Sink hot-water use profile

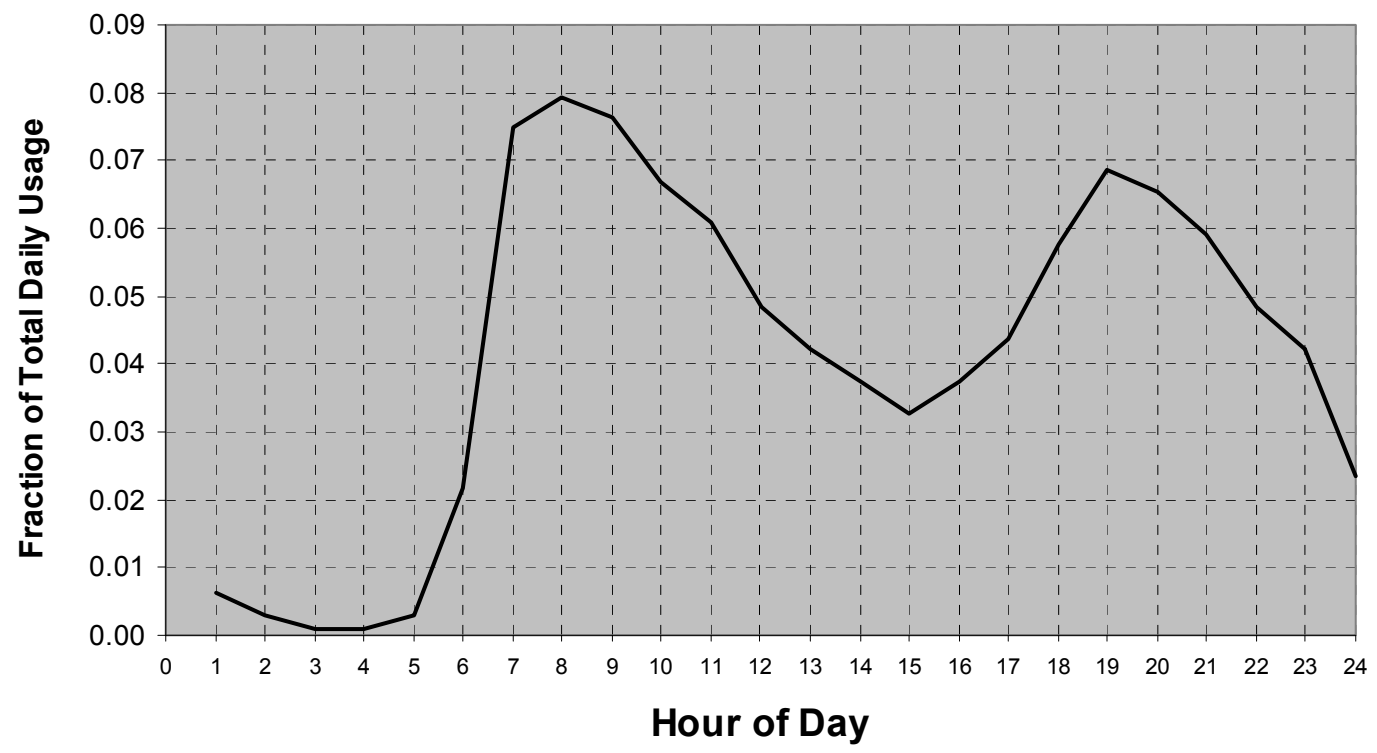

Figure 11. Combined domestic hot-water use profile

The mains water temperature for a typical house varies significantly depending on the location and time of year. The following equation, based on TMY2 data for the location of the Prototype, shall be used to determine the daily mains water temperature for both the Benchmark and the Prototype:

Equation 4: $\mathrm{T}_{\text {mains }}=\left(\mathrm{T}_{\mathrm{amb}, \mathrm{avg}}+\right.$ offset $)+$ ratio $*\left(\Delta \mathrm{T}_{\mathrm{amb}, \max } / 2\right) * \sin (0.986 *(\mathrm{day} \#-15-$ lag $)-90)$

where

$$
\begin{array}{ll}
\mathrm{T}_{\text {mains }} & =\text { mains (supply) temperature to domestic hot-water tank }\left({ }^{\circ} \mathrm{F}\right) \\
\mathrm{T}_{\text {amb,avg }} & =\text { annual average ambient air temperature }\left({ }^{\circ} \mathrm{F}\right) \\
\Delta \mathrm{T}_{\text {amb,max }} & =\text { maximum difference between monthly average ambient }
\end{array}
$$




$$
\begin{array}{ll} 
& \left.\quad \text { temperatures (e.g., } \mathrm{T}_{\text {amb,avg.july }}-\mathrm{T}_{\text {amb,avg,january }}\right)\left({ }^{\circ} \mathrm{F}\right) \\
0.986 & =\text { degrees/day }(360 / 365) \\
\text { day\# } & =\text { Julian day of the year }(1-365) \\
\text { offset } & =6^{\circ} \mathrm{F} \\
\text { ratio } & =0.4+0.01\left(\mathrm{~T}_{\text {amb,avg }}-44\right) \\
\text { lag } & =35-1.0\left(\mathrm{~T}_{\text {amb,avg }}-44\right) .
\end{array}
$$

This equation is based on analysis by Christensen and Burch of NREL using data for multiple locations, as compiled by Abrams and Shedd (Abrams 1996), Florida Solar Energy Center (Parker 2002), and Sandia National Laboratories (Kolb 2003). The offset, ratio, and lag factors were determined by fitting the available data. The climate-specific ratio and lag factors are consistent with water pipes being buried deeper in colder climates.

In order for the constant terms in the ratio and lag factors to be representative of an average climate, the data fitting was done relative to a nominal $\mathrm{T}_{\mathrm{amb}, \mathrm{avg}}=44^{\circ} \mathrm{F}$. The lag is relative to ambient air temperature, and $\mathrm{T}_{\mathrm{amb} \text {,minimum }}$ is assumed to occur in mid-January (day\# =15). The choices for these nominal values are not critical, because although different assumptions would change the constant terms in the ratio and lag factors, the coefficients would also change, so the prediction of $\mathrm{T}_{\text {mains }}$ values would be unchanged. For models that use average monthly mains temperature, day\# in Equation 4 shall be calculated using Equation 5.

$$
\begin{aligned}
& \text { Equation 5: day\# }=\mathbf{3 0} * \text { month\# - 15, } \\
& \text { where month } \#=\text { month of the year }(1-12) \text {. }
\end{aligned}
$$

An example using Equations 4 and 5 to determine the monthly mains temperature profile for Chicago, Illinois, is shown in Figure 12.

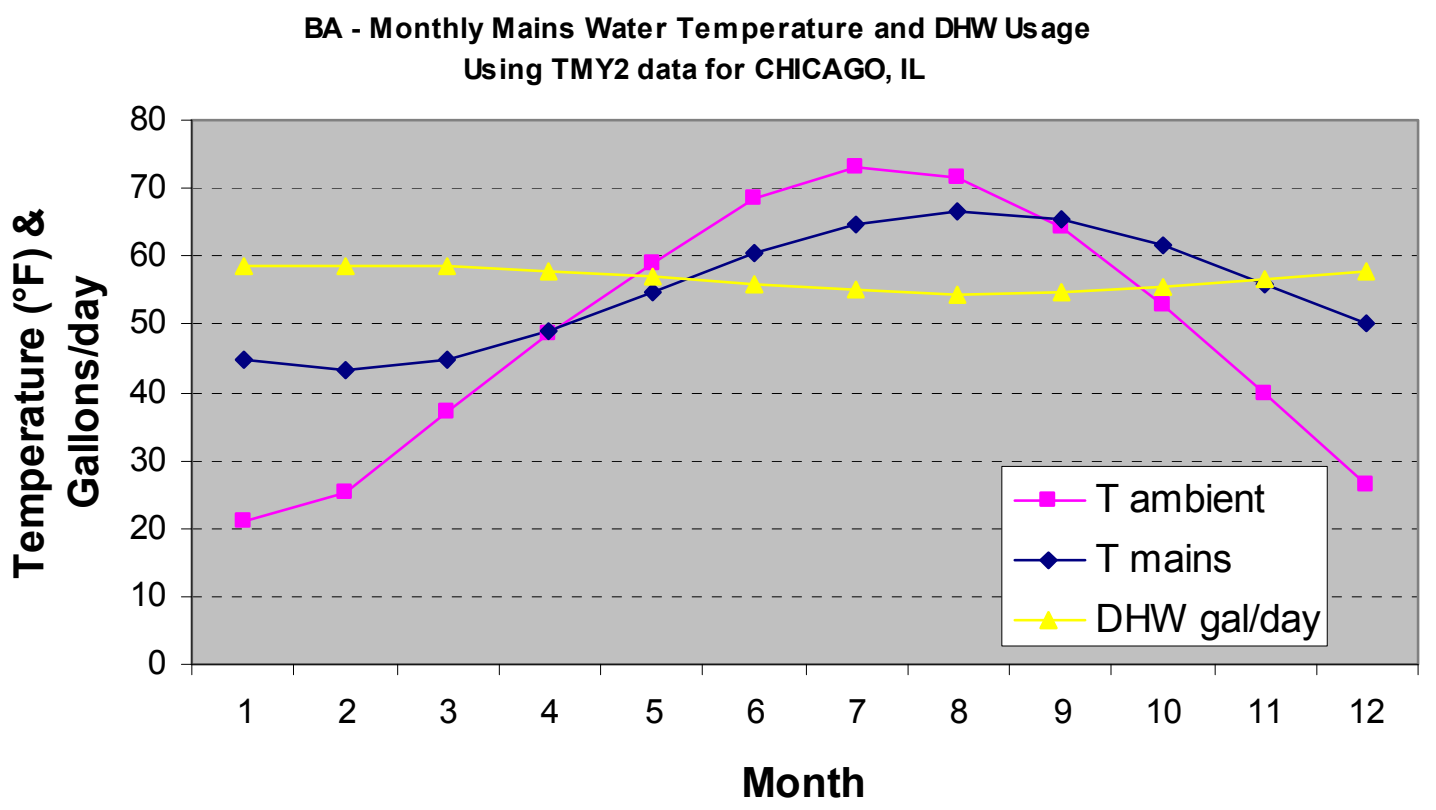

Figure 12. Mains temperature profile for Chicago 


\section{Air Infiltration and Ventilation}

The hourly natural air change rate for the Benchmark shall be calculated based on the Specific Leakage Area (SLA) determined using Equation 6:

\section{Equation 6: $\quad$ SLA $=$ ELA $/$ CFA $=0.00057$,}

where $\quad E L A=$ effective leakage area $\left(\mathrm{ft}^{2}\right)$, defined as the amount of open area that would result in the same total air exchange as the actual leakage area of the house at a pressure of $4 \mathrm{~Pa}$

$$
\mathrm{CFA}=\text { conditioned floor area }\left(\mathrm{ft}^{2}\right)
$$

When specifying natural infiltration for a Benchmark with either a directly or indirectly conditioned basement, the SLA shall be adjusted to account for the in-ground portions of the walls of the conditioned basement. Equation 7 shall be used to make this adjustment.

Equation 7: $\operatorname{SLA}_{\text {overall }}=\left[\left(\mathrm{CFA}_{\mathrm{bsmt}} * \mathrm{SLA}_{\mathrm{bsmt}}\right)+\left(\mathrm{CFA}_{\mathrm{a}-\mathrm{g}} * \mathrm{SLA}_{\mathrm{a}-\mathrm{g}}\right)\right] /\left[\mathrm{CFA}_{\text {total }}\right]$, where
SLA $\quad=\operatorname{ELA}\left(\mathrm{ft}^{2}\right) /$ CFA $\left(\mathrm{ft}^{2}\right)$
$\mathrm{SLA}_{\mathrm{a}-\mathrm{g}}=\mathrm{SLA}_{\mathrm{std}}$ (where subscript 'a-g' indicates above-grade or exposed)
$\mathrm{SLA}_{\mathrm{bsmt}}=\mathrm{SLA}_{\mathrm{std}} *$ (above-grade basement wall area)/(total basement wall area)
$\mathrm{SLA}_{\text {std }} \quad=0.00057$

This can be calculated by zone, applying $\mathrm{SLA}_{\mathrm{bsmt}}$ to the basement zone and $\mathrm{SLA}_{\text {std }}$ to the above-grade zone of the Benchmark and treating the energy balances separately for each zone. It can also be done by applying SLA overall $_{\text {to }}$ the combined spaces if the Benchmark is modeled as a single zone.

Additional air exchange due to mechanical ventilation shall be calculated assuming a balanced ventilation system with the same ventilation rate used for the Prototype, up to a maximum value consistent with the rate recommended by ASHRAE Standard 62.2. Ventilation air shall be added to the natural infiltration rate assuming no interactive effects and no heat recovery. The ventilation fan energy use for the Benchmark shall be calculated using a fan efficiency of $0.50 \mathrm{~W} / \mathrm{cfm}$.

Note that finished floor area is used in these equations instead of conditioned floor area. We believe that finished floor area more accurately represents the area that occupants use in their daily activities (see also the treatment of lighting and plug loads).

In addition to whole-house ventilation, the Benchmark shall include a kitchen range hood and a spot ventilation fan in each bathroom. The flow rates of each fan shall be the same as the Prototype, and the efficacy for each fan shall be $0.50 \mathrm{~W} / \mathrm{cfm}$. The kitchen range hood is assumed to operate 30 minutes per day, and each bathroom fan is assumed to operate 60 minutes per day.

\section{Lighting Equipment and Usage}

The total annual hard-wired lighting use for the Benchmark is determined using Equations 8-10. These equations are derived from data for both single-family and multi-family housing documented in a lighting study conducted by Navigant for DOE (Navigant Consulting 2002).

Equation 8: Interior hard-wired lighting $=0.8 *($ FFA $* 0.8+455) \mathrm{kWh} / \mathrm{yr}$, Equation 9: Garage lighting $=100 \mathrm{kWh} / \mathrm{yr}$, 


\section{Equation 10: Exterior lighting $=250 \mathrm{kWh} / \mathrm{yr}$,}

Annual hard-wired indoor lighting, in kilowatt-hours, represents approximately $80 \%$ of all indoor lighting and is expressed as a linear function of finished house area relative to a constant base value. Garage and exterior lighting are treated as constants. When combined with plug-in lighting (discussed in the next section), the total interior lighting calculated using this equation is in the middle range of residential lighting energy use found in other lighting references, as shown in Figure 13, including Huang and $\mathrm{Gu}$ (2002), the 1993 RECS (DOE 1996), a Florida Solar Energy Center study (Parker et al 2000), default lighting for Visual DOE software (Eley 2002), a lighting study conducted by Navigant for DOE (Navigant Consulting 2002), and two other studies in Grays Harbor, Washington (Manclark and Nelson 1992), and Southern California Edison (SCE 1993).

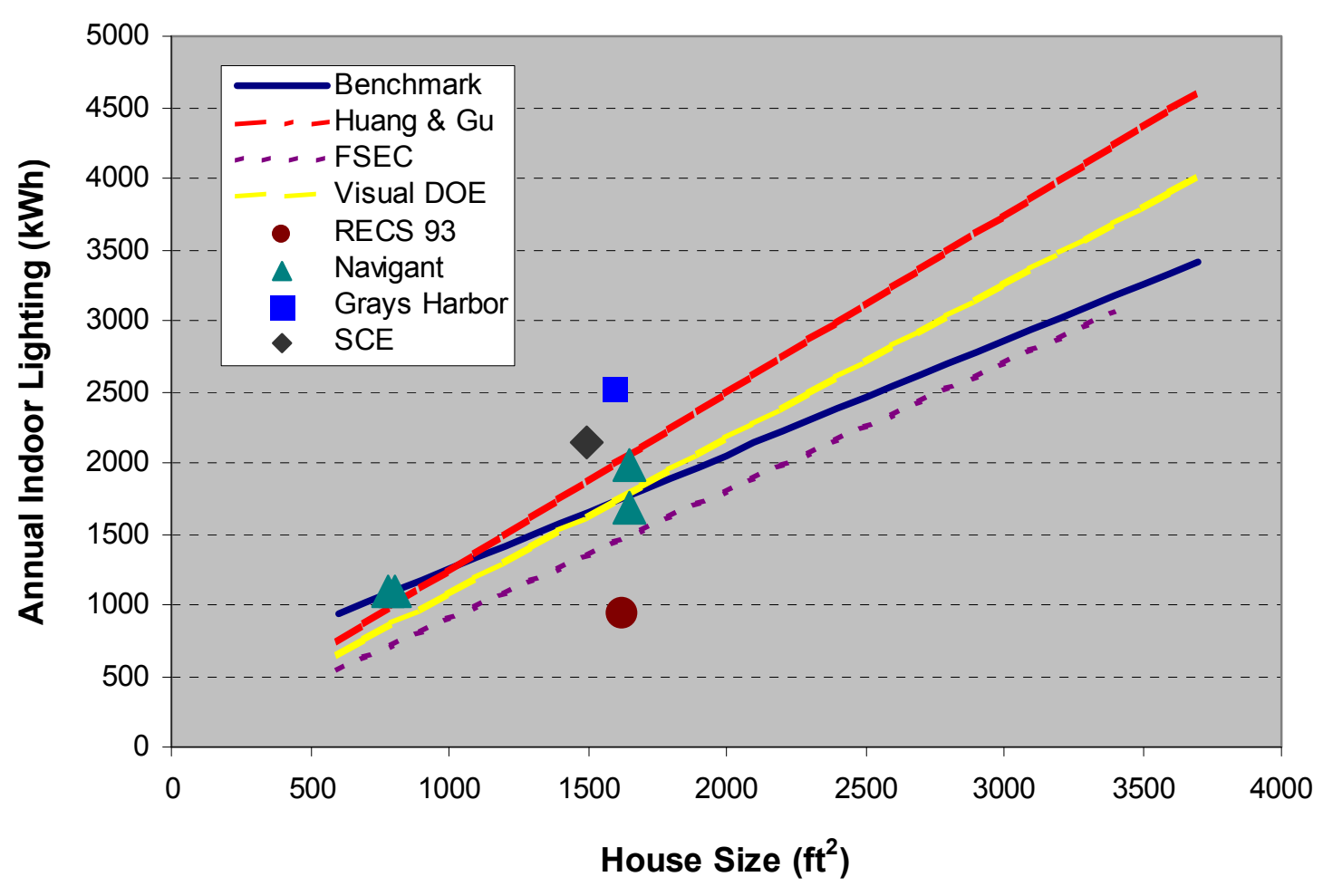

Figure 13. Comparison of Benchmark lighting equation to other references

The Benchmark lighting budget is based on an assumption that $86 \%$ of all lamps are incandescent, and the remaining 14\% are fluorescent. This is consistent with the source data set from 161 homes monitored by Tacoma Public Utilities (TPU) for the Bonneville Power Administration, which was the basis for the Navigant study. Although the core data set used in this study is the most complete and comprehensive residential lighting data set that we have identified, it is nevertheless limited in terms of geographic location, number of homes, length of study, percent of fixtures monitored, and type of homes studied. The Navigant report includes an appendix providing information about the characteristics of the homes monitored in the TPU study.

If a comprehensive lighting plan has not been developed for the Prototype house, and only fluorescent and incandescent lamps are installed, then a simplified approach may be used to estimate energy savings compared to the Benchmark using Equation 11. This equation is based on an assumption that the efficacies of incandescent and fluorescent light fixtures are the same in the Prototype as they were in the TPU study, and that fluorescent lighting is distributed equally among all hard-wired fixtures, including garage and exterior lights. 
Equation 11: Prototype hard-wired lighting $(\mathrm{kWh} / \mathrm{yr})=\mathrm{L}_{\mathrm{B}} *\left(1.12 * \mathrm{~F}_{\mathrm{I}}+0.279 * \mathrm{~F}_{\mathrm{F}}\right)$

where $L_{B}=$ hard-wired interior, exterior, or garage lighting for the Benchmark from Equation 8,9 , or $10(\mathrm{kWh} / \mathrm{yr})$

$\mathrm{F}_{\mathrm{I}}=$ fraction of hard-wired lamps in the Prototype that are incandescent

$\mathrm{F}_{\mathrm{F}}=$ fraction of hard-wired lamps in the Prototype that are fluorescent

The annual average normalized daily load shape for interior lighting use is shown in Figure 14, based on a draft LBNL report by Huang and Gu (2002). This load shape is also used for exterior and garage lighting. Monthly variations in load shape and lighting energy use due to changes in the length of days can be accounted for, as long as the variation is applied to all the simulation models and total annual energy use remains the same.

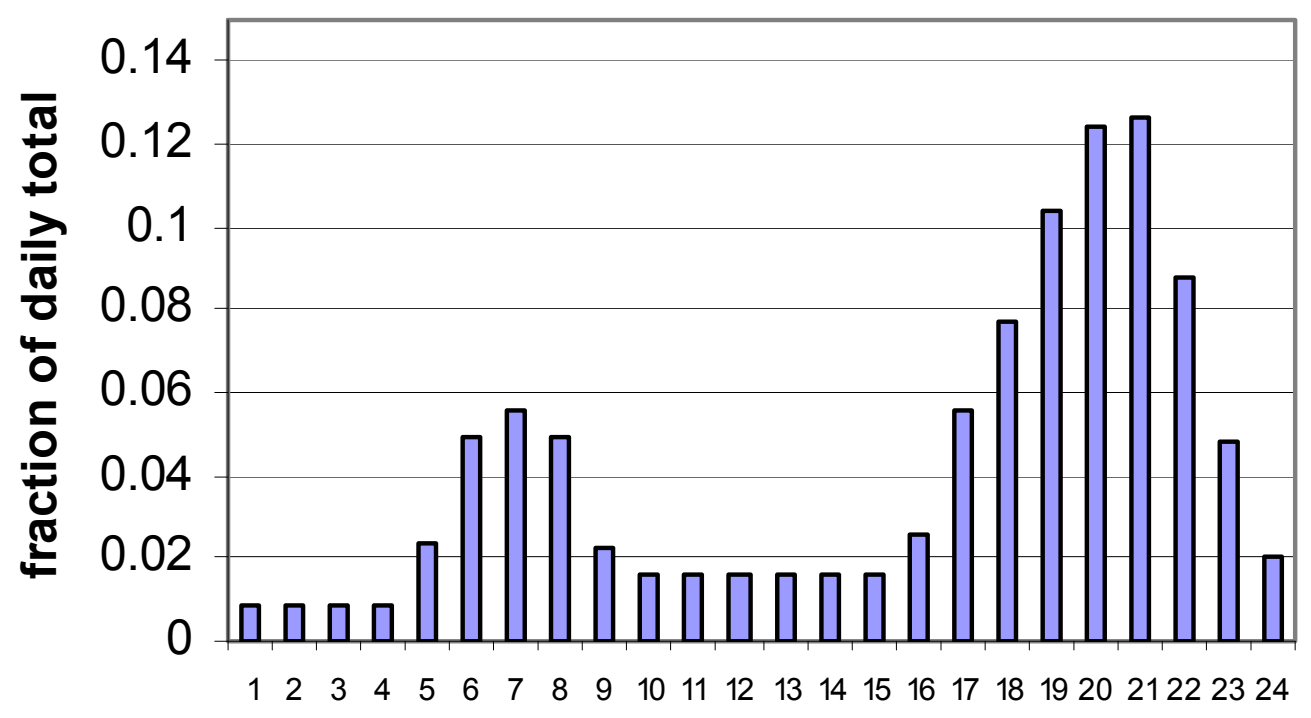

Figure 14. Interior lighting profile (Built up from detailed profiles)

Energy savings may be calculated on the basis of a number of usage variations, depending on the capability of the modeling tool. Variations include day types (weekday vs. weekend), occupancy types (day-use vs. non-day-use or "nuclear" vs. "yuppie"), season (summer vs. winter), and room types (living area vs. bedroom area).

Individual normalized profiles can be "rolled up" to various levels of detail appropriate to the simulation model. An example of one detailed set of profiles developed by NREL is shown in Figure 15. Other profiles are included in spreadsheets available on the Building America Web site (http://www.eere.energy.gov/buildings/building_america/pa_resources.html). 


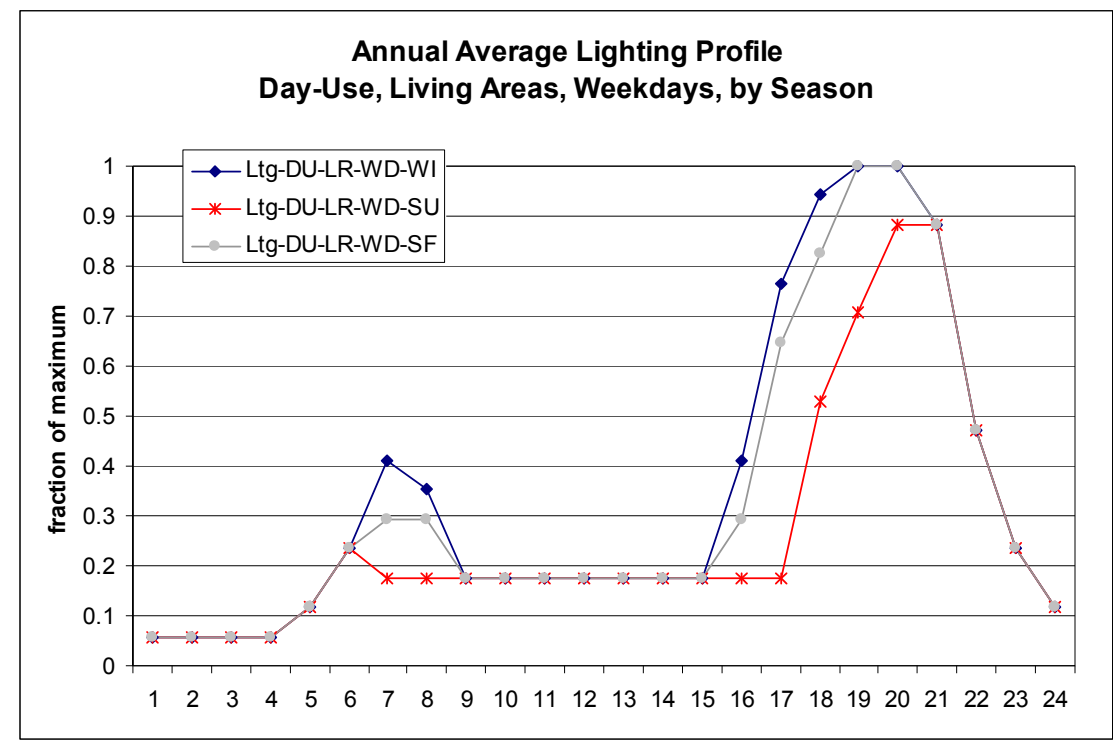

Figure 15. Example of a detailed lighting profile (expressed as fraction of peak daily lighting energy)

The lighting plans for the Prototype and Benchmark should be based on the same hours of operation unless the Prototype includes specific design measures that alter the operating time of the lighting system, such as occupancy sensors, dimming switches, or a building automation system. Average operating hours estimated in the Navigant study are generally a good starting point (Table 11), but there may be substantial differences between typical lighting designs found in the TPU sample and the lighting design developed in conjunction with the architecture of the Prototype. The analyst must ultimately apply good engineering judgment when specifying operating hours for the lighting system.

Table 11. Average Lighting Operating Hours for Common Room Types in a Sample of 161 Homes in the Pacific Northwest

\begin{tabular}{|l|c|l|c|}
\hline \multicolumn{1}{|c|}{ Room Type } & $\begin{array}{c}\text { Operation } \\
\text { (Hours/Day/Room) }\end{array}$ & Room Type & $\begin{array}{c}\text { Operation } \\
\text { (Hours/Day/Room) }\end{array}$ \\
\hline Bathroom & 1.8 & Kitchen & 3.0 \\
\hline Bedroom & 1.1 & Living Room & 2.5 \\
\hline Closet & 1.1 & Office & 1.7 \\
\hline Dining Room & 2.5 & Outdoor & 2.1 \\
\hline Family Room & 1.8 & Utility Room & 2.0 \\
\hline Garage & 1.5 & Other & 0.8 \\
\hline Hall & 1.5 & & \\
\hline
\end{tabular}

Source: Navigant Consulting 2002

\section{Appliances and Miscellaneous Electric Loads}

As with lighting, several characteristics must be defined for appliances and miscellaneous electric loads (MELs): the amount of the load, the schedule of the load, the location of the load, the fraction of the load that becomes a sensible load, and the fraction of the load that becomes a latent load. Though the internal load may be treated as an aggregate, the energy consumption for each end use must be considered separately. A breakdown of annual energy consumption and associated internal loads for major appliances and other equipment is shown in Table 12a. Not all of the energy consumed by appliances is converted into internal load; much of the waste heat is exhausted to the outside or released down the drain in the form of hot water. The appliance loads were derived by NREL from EnergyGuide labels, a 
Navigant analysis of typical models available on the market that meet current NAECA appliance standards, and several other studies.

For a house of typical size (1000-3000 $\left.\mathrm{ft}^{2}\right)$, the loads from the occupants and most appliances are assumed to be a function of the number of bedrooms and the finished floor area. The exceptions are the refrigerator and certain miscellaneous gas and electric loads, which are assumed to be constant regardless of the number of bedrooms. The general relationship between appliance loads, number of bedrooms, and house size, was derived empirically from the 2001 RECS. The sensible and latent load fractions were developed based on engineering analysis and judgment.

Miscellaneous loads are broken into variable electric loads and fixed gas and electric loads. By definition, energy savings are not calculated for improvements to fixed loads because an analysis methodology has not yet been established. However, NREL has developed a methodology for calculating energy savings associated with the most common miscellaneous electric loads encountered in a typical house, which we refer to as variable MELs. Approximately 100 MELs in this category are listed in Table 13. If the analyst chooses to use anything other than the Benchmark MEL values for the Prototype, he or she must use the MEL Analysis Spreadsheet for new construction posted on the Building America Web site (http://www.eere.energy.gov/buildings/building_america/pa_resources.html) to calculate energy savings, latent and sensible loads, and the split between standby and operating energy. This spreadsheet only allows the analyst to change the quantity and the operating and standby power levels of MELs in the Prototype. Operating hours cannot be changed, but a lower "effective" power draw may be used if occupancy sensors or other controls are used to turn off power to MELs that are not in use. In addition, only those MELs that are installed or provided by the builder may be included in the energy savings analysis. The remaining MELs in the Prototype revert to the default values used for the Benchmark. References for the typical MEL characteristics used in the calculations are documented in the spreadsheet.

The MEL end use is assumed to be primarily a function of finished floor area. A multiplier is applied if the prototype is located in one of the four most populated states as determined in the EIA Residential Energy Consumption Survey (RECS) (DOE 2001). Multipliers for these four states were estimated based on the final electric end-use regression equations developed for the 2001 RECS, substituting national average values for known housing characteristics and physical traits of the occupants (such as number of bedrooms, number of ceiling fans, and age of homeowner) and removing end-uses that are disaggregated in the Benchmark (such as lighting and clothes dryer). The resulting multipliers are listed in Table 12b. The multiplier is 1.0 for all states not listed because insufficient information is available about the magnitude of plug loads in those states.

Table 12a. Annual Appliance and Equipment Loads for the Benchmark ${ }^{3}$

\begin{tabular}{|l|c|c|c|c|}
\hline Appliance & $\begin{array}{c}\text { Electricity } \\
(\mathrm{kWh} / \mathrm{yr})\end{array}$ & $\begin{array}{c}\text { Natural Gas } \\
\text { (therms/yr) }\end{array}$ & $\begin{array}{c}\text { Sensible Load } \\
\text { Fraction }\end{array}$ & Latent Load Fractior \\
\hline Refrigerator & 669 & & 1.00 & 0.00 \\
\hline Clothes Washer (3 ft $\left.{ }^{3} \mathrm{drum}\right)$ & $52.5+17.5 \times \mathrm{N}_{\mathrm{br}}$ & & 0.80 & 0.00 \\
\hline Clothes Dryer (Electric) & $418+139 \times \mathrm{N}_{\mathrm{br}}$ & & 0.15 & 0.05 \\
\hline Clothes Dryer (Gas) & $38+12.7 \times \mathrm{N}_{\mathrm{br}}$ & $26.5+8.8 \times \mathrm{N}_{\mathrm{br}}$ & $\begin{array}{c}1.00 \text { (Electric) } \\
0.10 \text { (Gas) }\end{array}$ & $\begin{array}{c}0.00 \text { (Electric) } \\
0.05 \text { (Gas) }\end{array}$ \\
\hline $\begin{array}{l}\text { Dishwasher (8 place } \\
\text { settings) }\end{array}$ & $103+34.3 \times \mathrm{N}_{\mathrm{br}}$ & & 0.60 & 0.15 \\
\hline Range (Electric) & $302+101 \times \mathrm{N}_{\mathrm{br}}$ & & 0.40 & 0.30 \\
\hline Range (Gas) & & $22.5+7.5 \times \mathrm{N}_{\mathrm{br}}$ & 0.30 & 0.20 \\
\hline
\end{tabular}

\footnotetext{
${ }^{3}$ End-use loads in this table include only energy used within the machine. Associated domestic hot water use is treated separately (see "Domestic Hot Water"). The Building America Analysis Spreadsheet on the Building America Web site (http://www.eere.energy.gov/buildings/building_america/pa_resources.html) can assist with the calculation of this split for an energy-efficient clothes washer or dishwasher based on the Energy Guide label.
} 


\begin{tabular}{|c|c|c|c|c|}
\hline Plug-In Lighting & $\left.0.2^{*}\left(\mathrm{FFA}^{*} 0.8+455\right)\right]$ & & 1.00 & 0.00 \\
\hline $\begin{array}{l}\text { Variable Miscellaneous } \\
\text { Electric Loads (MELs) }\end{array}$ & $\begin{array}{l}\left(1231+194 \times \mathrm{N}_{\mathrm{br}}+\right. \\
0.316 \times \mathrm{FFA}) \times \mathrm{F}_{\mathrm{s}}\end{array}$ & & 0.81 & 0.02 \\
\hline $\begin{array}{l}\text { Fixed Miscellaneous Loads } \\
\text { (Gas/Electric) }\end{array}$ & $\begin{array}{l}\left(180+30 \times \mathrm{N}_{\mathrm{br}}+\right. \\
0.047 \times \mathrm{FFA}) \times \mathrm{F}_{\mathrm{s}}\end{array}$ & $\begin{array}{r}\left(5.8+1.0 \times \mathrm{N}_{\mathrm{br}^{+}}\right. \\
0.0015 \times \mathrm{FFA}) \times \mathrm{F}_{\mathrm{s}}\end{array}$ & 0.13 & 0.25 \\
\hline $\begin{array}{l}\text { Fixed Miscellaneous Loads } \\
\text { (All-Electric) }\end{array}$ & $\begin{array}{l}\left(349+58 \times \mathrm{N}_{\mathrm{br}}+\right. \\
0.091 \times \mathrm{FFA}) \times \mathrm{F}_{\mathrm{s}}\end{array}$ & & 0.13 & 0.25 \\
\hline
\end{tabular}

Table 12b. Plug load multipliers for four most populated states $\left(F_{s}\right)$.

\begin{tabular}{|l|c|}
\hline \multicolumn{1}{|c|}{ State } & Multiplier $\left(\mathbf{F}_{\mathbf{S}}\right)$ \\
\hline New York & 0.82 \\
\hline California & 0.77 \\
\hline Florida & 0.94 \\
\hline Texas & 1.11 \\
\hline $\begin{array}{l}\text { All other States and } \\
\text { territories }\end{array}$ & 1.00 \\
\hline
\end{tabular}


Table 13. Benchmark Annual Energy Consumption for Miscellaneous Electric and Gas Loads. (three-bedroom house, $1920 \mathrm{ft}^{2}$ )

\begin{tabular}{|c|c|c|c|c|c|c|c|}
\hline $\begin{array}{c}\text { Miscellaneous Electric } \\
\text { Load }\end{array}$ & $\begin{array}{l}\text { Avg } \\
\text { Units/ } \\
\text { Hshld }\end{array}$ & $\begin{array}{l}\text { Energyl } \\
\text { Unit } \\
\text { kWh/yr }\end{array}$ & $\begin{array}{l}\text { Energy/ } \\
\text { Hshld } \\
\text { kWh/yr }\end{array}$ & Miscellaneous Electric Load & $\begin{array}{l}\text { Avg } \\
\text { Units/ } \\
\text { Hshld }\end{array}$ & $\begin{array}{l}\text { Energy/ } \\
\text { Unit } \\
\text { kWh/yr }\end{array}$ & $\begin{array}{l}\text { Energy/ } \\
\text { Hshld } \\
\text { kWh/yr }\end{array}$ \\
\hline Hard-Wired & & & & Home Office & & & \\
\hline Fan (Ceiling) & 1.400 & 50.0 & 70.0 & Laptop PC (Plugged In) & 0.152 & 47.0 & 7.1 \\
\hline Air Handler Standby Losses & 0.800 & 67.2 & 53.8 & Desktop PC w/ Speakers & 0.592 & 143.9 & 85.2 \\
\hline HVAC Controls & 1.000 & 20.3 & 20.3 & PC Monitor & 0.592 & 119.8 & 70.9 \\
\hline Home Security System & 0.187 & 195.1 & 36.5 & Printer (Laser) & 0.049 & 92.5 & 4.5 \\
\hline Ground Fault Circuit Interrupter & 3.850 & 6.2 & 23.9 & Printer (Inkjet) & 0.118 & 39.0 & 4.6 \\
\hline Sump Pump & 0.099 & 40.0 & 3.9 & Dot Matrix Printer & 0.030 & 115.0 & 3.5 \\
\hline Heat Lamp & 0.010 & 13.0 & 0.1 & DSL/Cable Modem & 0.200 & 17.6 & 3.5 \\
\hline Garage Door Opener & 0.266 & 35.0 & 9.3 & Scanner & 0.050 & 49.0 & 2.4 \\
\hline Carbon Monoxide Detector & 0.260 & 17.5 & 4.6 & Copy Machine & 0.020 & 25.0 & 0.5 \\
\hline Smoke Detectors & 0.840 & 3.5 & 2.9 & Fax Machine & 0.030 & 326.3 & 9.8 \\
\hline Garbage Disposal & 0.404 & 10.0 & 4.0 & Bathroom & & & \\
\hline Doorbell & 0.670 & 44.0 & 29.5 & Hair Dryer & 0.837 & 0.6 & 0.5 \\
\hline Home Entertainment & & & & Curling Iron & 0.532 & 1.0 & 0.5 \\
\hline First Color TV & 0.986 & 215.5 & 212.5 & Electric Shaver & 0.470 & 12.8 & 6.0 \\
\hline Second Color TV & 0.669 & 112.7 & 75.4 & Electric Toothbrush Charger & 0.118 & 19.3 & 2.3 \\
\hline Third Color TV & 0.296 & 66.7 & 19.7 & Garage \& Workshop & & & \\
\hline Fourth Color TV & 0.104 & 52.1 & 5.4 & Auto Block Heater & 0.019 & 250.0 & 4.8 \\
\hline Fifth or More Color TV & 0.028 & 45.8 & 1.3 & Lawn Mower (Electric) & 0.059 & 42.9 & 2.5 \\
\hline First VCR & 0.876 & 71.3 & 62.5 & Heat Tape & 0.030 & 100.0 & 3.0 \\
\hline Second VCR & 0.320 & 68.9 & 22.1 & Kiln & 0.020 & 50.0 & 1.0 \\
\hline Third or More VCR & 0.072 & 68.6 & 4.9 & Pipe and Gutter Heaters & 0.010 & 53.0 & 0.5 \\
\hline DVD Player & 0.472 & 50.1 & 23.7 & Shop Tools & 0.130 & 26.4 & 3.4 \\
\hline Video Gaming System & 0.631 & 20.4 & 12.9 & Other & & & \\
\hline Clock Radio & 1.260 & 14.9 & 18.8 & Humidifier & 0.150 & 100.0 & 15.0 \\
\hline Boombox / Portable Stereo & 0.670 & 16.8 & 11.3 & Water Bed & 0.066 & 1068.0 & 70.5 \\
\hline Compact Stereo & 0.460 & 112.3 & 51.6 & Sm Freshwater Aquarium (5-20 gal) & 0.024 & 105.0 & 2.5 \\
\hline Component / Rack Stereo & 0.730 & 153.0 & 111.7 & Md Freshwater Aquarium (20-40 gal) & 0.024 & 180.0 & 4.3 \\
\hline Power Speakers & 0.296 & 24.4 & 7.2 & Lg Freshwater Aquarium (40-60 gal) & 0.024 & 340.0 & 8.1 \\
\hline Subwoofer & 0.099 & 68.3 & 6.7 & Small Marine Aquarium (5-20 gal) & 0.002 & 245.0 & 0.6 \\
\hline Radio & 0.493 & 9.1 & 4.5 & Medium Marine Aquarium (20-40 gal) & 0.002 & 615.0 & 1.5 \\
\hline Equalizer & 0.049 & 14.7 & 0.7 & Large Marine Aquarium (40-60 gal) & 0.002 & 740.0 & 1.8 \\
\hline Satellite Dish Box & 0.202 & 131.7 & 26.6 & Vacuum Cleaner (Upright) & 0.946 & 31.0 & 29.3 \\
\hline Cable Box & 0.637 & 152.7 & 97.3 & Clock & 0.956 & 26.0 & 24.8 \\
\hline Kitchen & & & & Cordless Phone & 0.601 & 23.2 & 13.9 \\
\hline Microwave & 0.933 & 135.1 & 126.1 & Cell Phone Charger & 0.450 & 77.4 & 34.8 \\
\hline Freezer & 0.323 & 935.0 & 302.0 & Electric Blanket & 0.286 & 120.0 & 34.3 \\
\hline Extra Refrigerator & 0.179 & 1100.0 & 196.9 & Answering Machine & 0.650 & 33.5 & 21.8 \\
\hline Coffee Maker (Drip) & 0.685 & 99.3 & 68.0 & Battery Charger & 0.437 & 14.8 & 6.5 \\
\hline Coffee Maker (Percolator) & 0.167 & 65.0 & 10.9 & Fan (Portable) & 0.946 & 11.3 & 10.7 \\
\hline Toaster Oven & 0.345 & 50.0 & 17.3 & Air Cleaner & 0.217 & 65.7 & 14.2 \\
\hline Toaster & 0.837 & 43.7 & 36.6 & Vacuum Cleaner (Cordless) & 0.207 & 36.5 & 7.6 \\
\hline Waffle Iron & 0.325 & 25.0 & 8.1 & Heating Pads & 0.670 & 3.0 & 2.0 \\
\hline Blender & 0.788 & 7.0 & 5.5 & Surge Protector / Power Strip & 0.360 & 3.9 & 1.4 \\
\hline Can Opener & 0.650 & 3.0 & 2.0 & Timer (Lighting) & 0.280 & 20.1 & 5.6 \\
\hline Electric Grill & 0.010 & 180.0 & 1.8 & Timer (Irrigation) & 0.050 & 45.2 & 2.3 \\
\hline Hand Mixer & 0.877 & 2.0 & 1.8 & Iron & 0.847 & 53.0 & 44.9 \\
\hline Electric Griddle & 0.256 & 6.0 & 1.5 & Baby Monitor & 0.100 & 22.8 & 2.3 \\
\hline Popcorn Popper & 0.305 & 5.0 & 1.5 & Fixed MELs & & & \\
\hline Espresso Machine & 0.069 & 19.0 & 1.3 & Pool Heater (Electric) & 0.004 & 2300.0 & 9.2 \\
\hline Instant Hot-water Dispenser & 0.006 & 160.0 & 1.0 & Pool Pump (Electric) & 0.066 & 2228.3 & 147.1 \\
\hline Hot Plate & 0.236 & 30.0 & 7.1 & Hot Tub / Spa Heater (Electric) & 0.056 & 1704.0 & 95.4 \\
\hline Food Slicer & 0.414 & 1.0 & 0.4 & Hot Tub / Spa Pump (Electric) & 0.094 & 460.0 & 43.2 \\
\hline Electric Knife & 0.374 & 1.0 & 0.4 & Well Pump (Electric) & 0.129 & 400.0 & 51.6 \\
\hline Broiler & 0.010 & 80.0 & 0.8 & Coral Reef Aquarium (Electric) & 0.001 & 4500.0 & 3.6 \\
\hline Deep Fryer & 0.148 & 20.0 & 3.0 & Gas Fireplace & 0.035 & 1760.0 & 60.9 \\
\hline Bottled Water & 0.010 & 300.0 & 3.0 & Gas Grill & 0.029 & 879.0 & 25.5 \\
\hline Trash Compactor & 0.010 & 50.0 & 0.5 & Gas Lighting & 0.005 & 557.0 & 2.9 \\
\hline \multirow[t]{4}{*}{ Slow Cooker / Crock Pot } & 0.581 & 16.0 & 9.3 & Pool Heater (Gas) & 0.024 & 6506.0 & 158.7 \\
\hline & & & & Hot Tub / Spa Heater (Gas) & 0.038 & 2374.0 & 90.2 \\
\hline & & & & Other & 1.000 & 9.4 & 9.4 \\
\hline & & & & Total MEL Load & & & 3117 \\
\hline
\end{tabular}


The hourly, normalized load shape for combined residential equipment use is shown in Figure 16, and is based on the ELCAP study of household electricity use in the Pacific Northwest (Pratt et al 1989). In most situations, this profile is adequate for simulating all electric and gas end-uses except space conditioning and hot water. However, because some individual end-use profiles are nearly constant (such as refrigerator and transformer loads) and some are highly dependent on time of day (such as the range and dishwasher), we have also developed a series of normalized hourly profiles for major appliances and plug loads, shown in Figures 17-22. Numerical values associated with these profiles can be found in the Building America Analysis Spreadsheet posted on the Building America Web site (http://www.eere.energy.gov/buildings/building_america/pa_resources.html). The hourly profiles for machine energy usage in the clothes washer and dishwasher are identical to those provided earlier in the section on DHW (see Figures 6-7). The profile for plug-in lighting is the same as the profile for hardwired lighting presented in Figure 14.

All hourly end-use profiles were taken from the ELCAP study, except the profile for "Other Appliance and Plug Loads," which was derived by subtracting the energy consumption profiles for the major appliances from the combined profile for all equipment, assuming an all-electric, $1800-\mathrm{ft}^{2}$, three-bedroom house in Memphis, Tennessee. Internal sensible and latent loads from appliances and plug loads shall be modeled using the same profile used for end-use consumption. Appliance loads may be modeled in either the living spaces or bedroom spaces, depending on their location in the Prototype.

Large end uses in the Prototype that are not part of typical houses (such as swimming pools, Jacuzzis, and workshops) are not included in the models for either the Prototype or the Benchmark. The efficiency of these end uses should be addressed in a separate analysis.

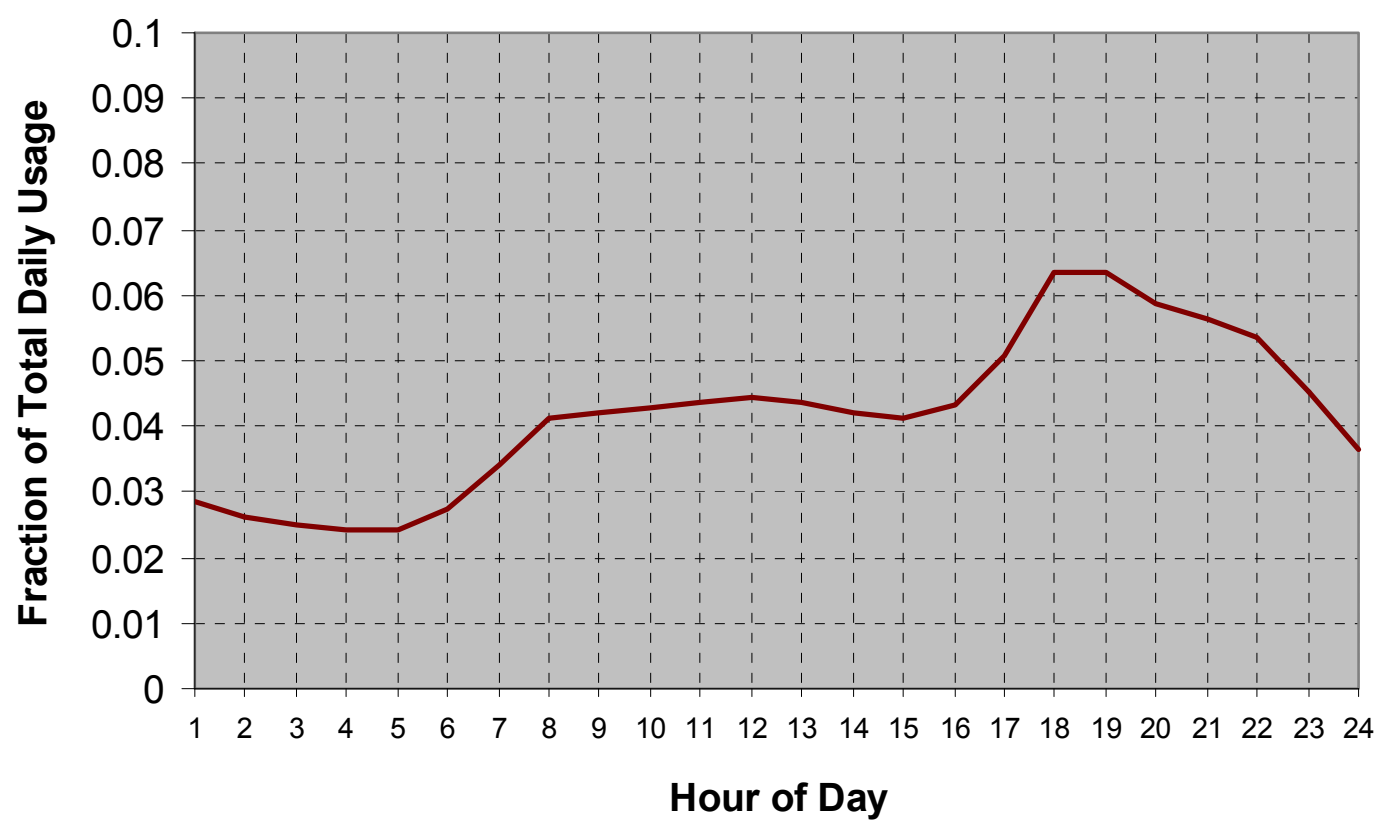

Figure 16. Total combined residential equipment profile (Pratt et al 1989) 


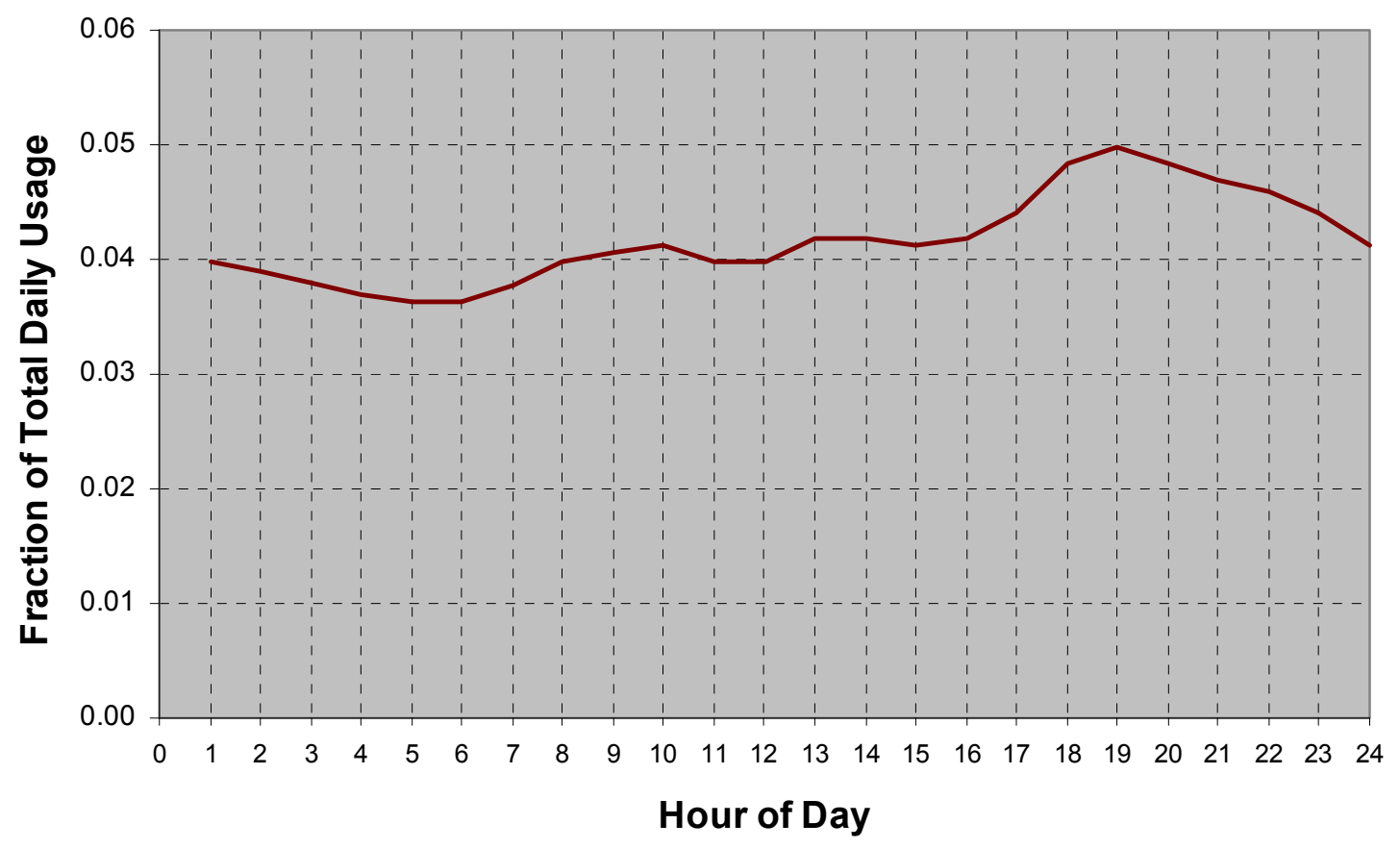

Figure 17. Refrigerator normalized energy use profile (Pratt et al 1989)

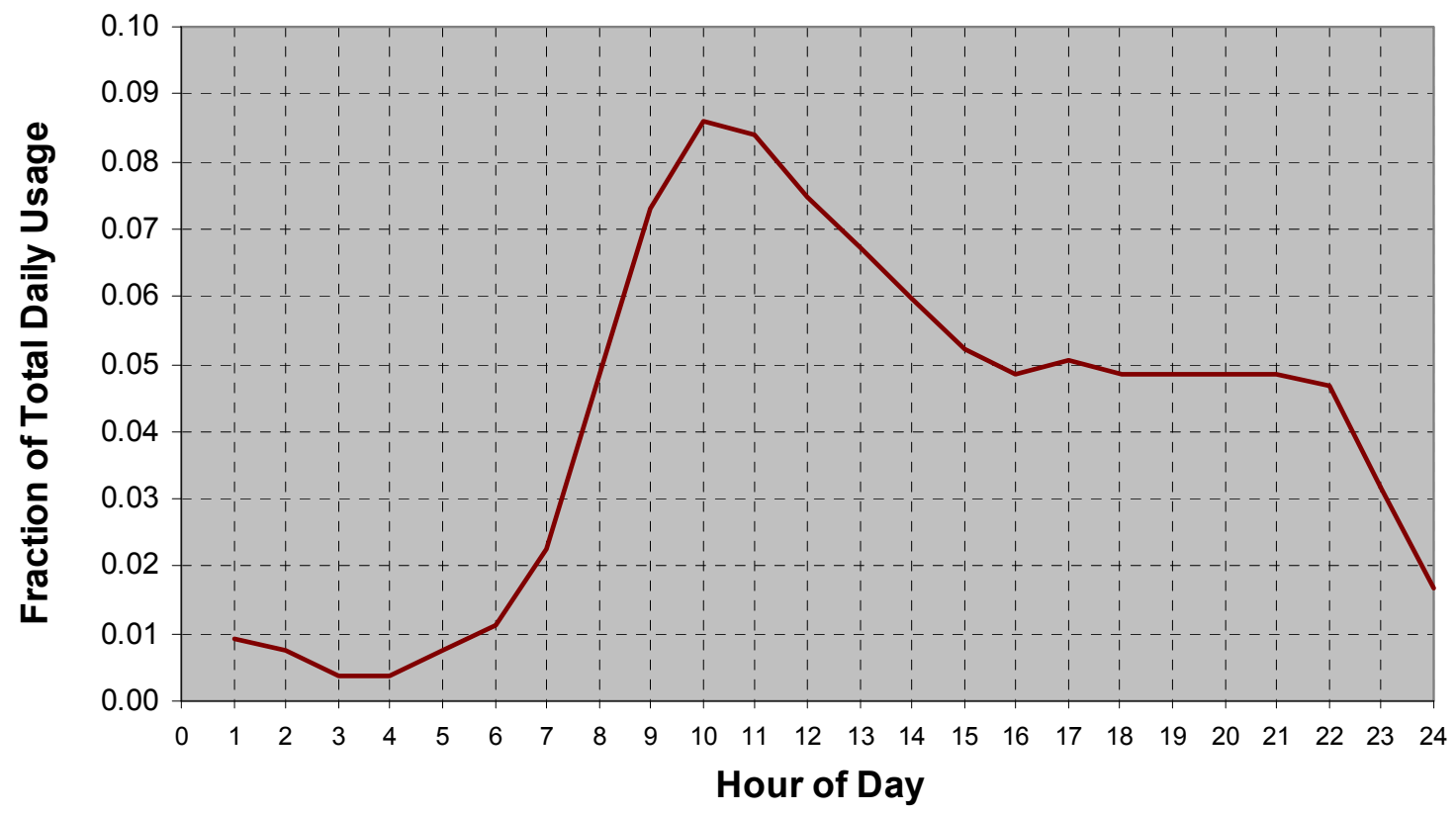

Figure 18. Clothes washer normalized machine energy use profile (Pratt et al 1989) 


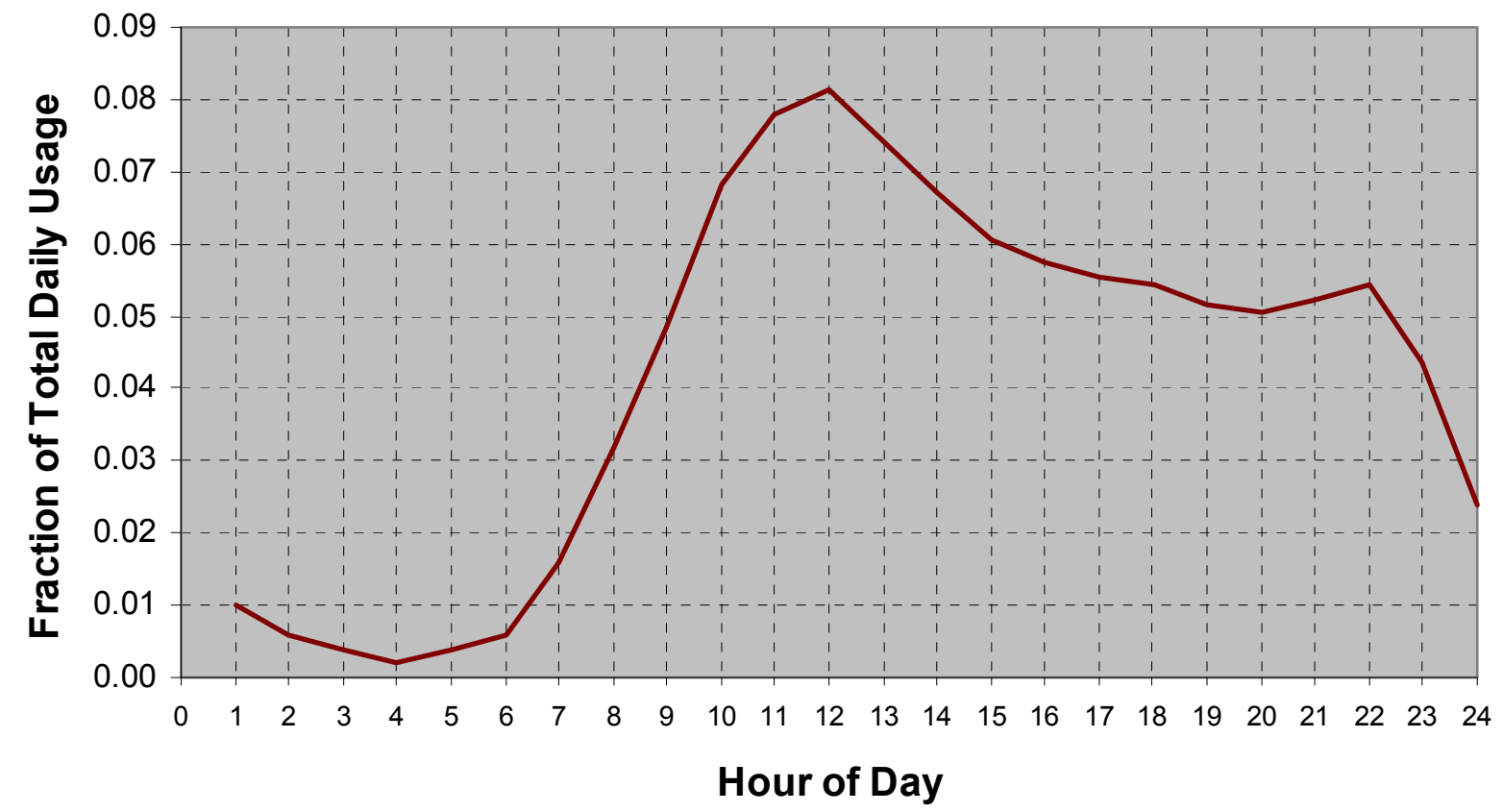

Figure 19. Clothes dryer normalized energy use profile (Pratt et al 1989)

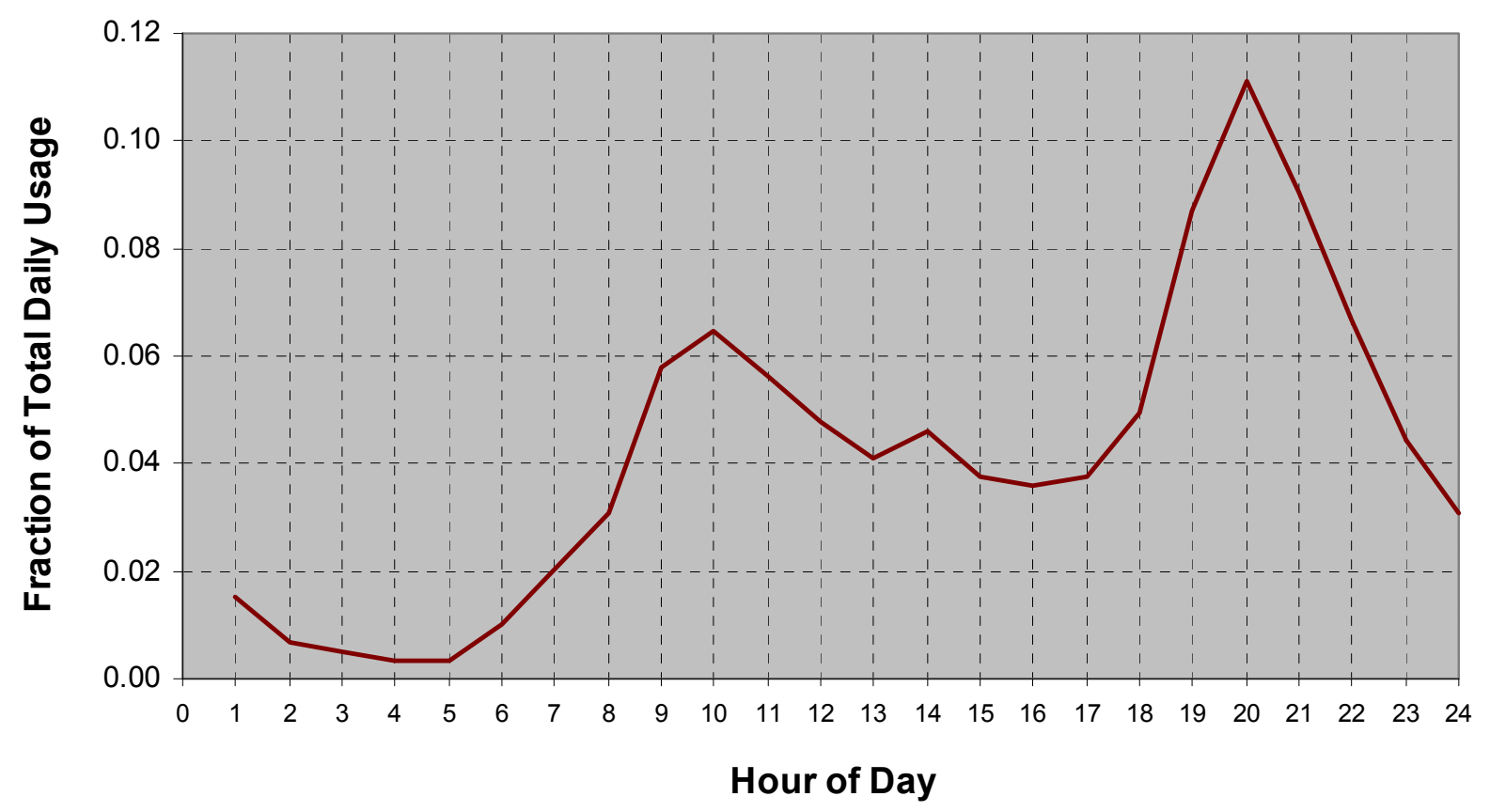

Figure 20. Dishwasher normalized energy use profile (Pratt et al 1989) 


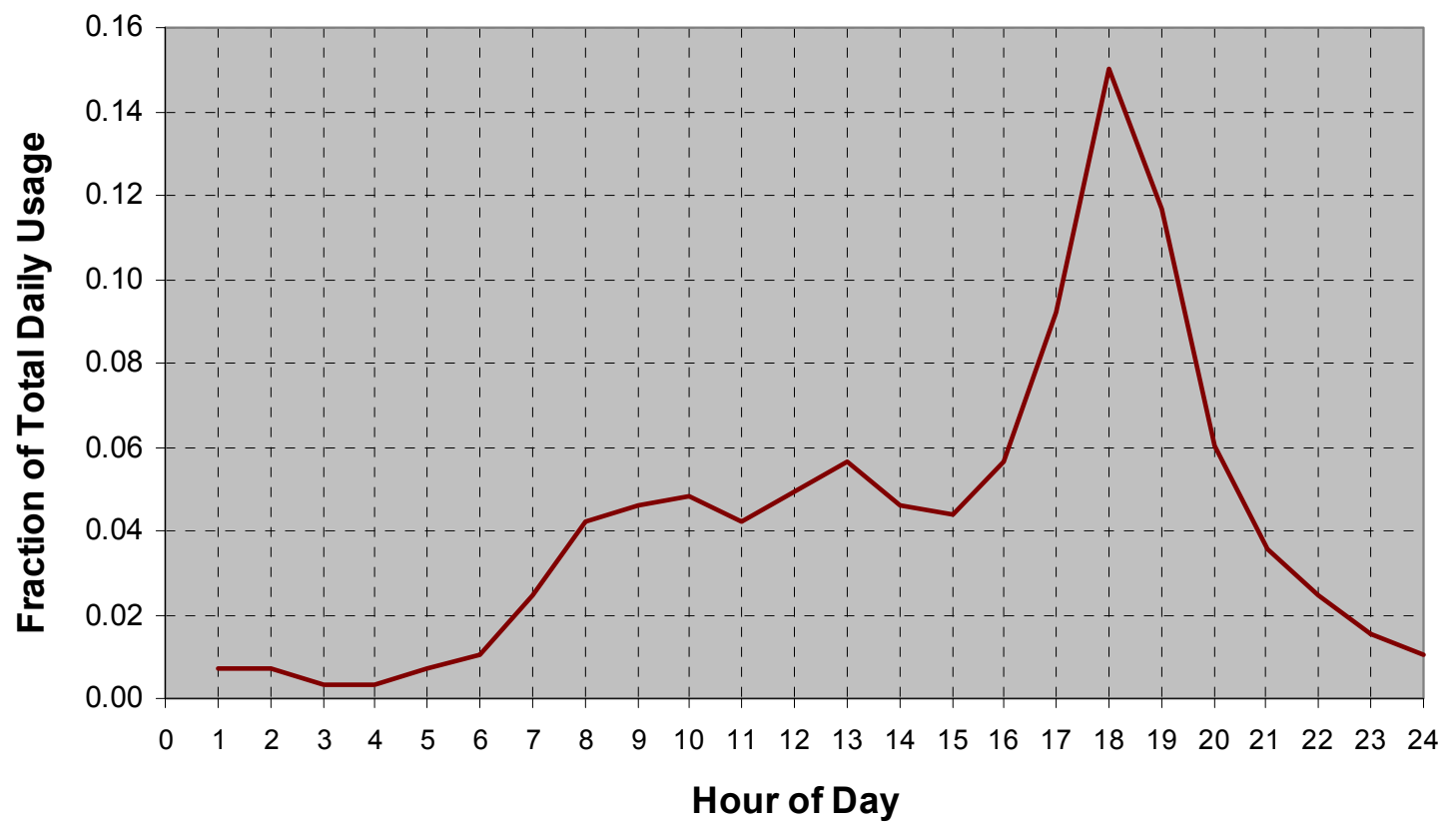

Figure 21. Range/oven normalized energy use profile (Pratt et al 1989)

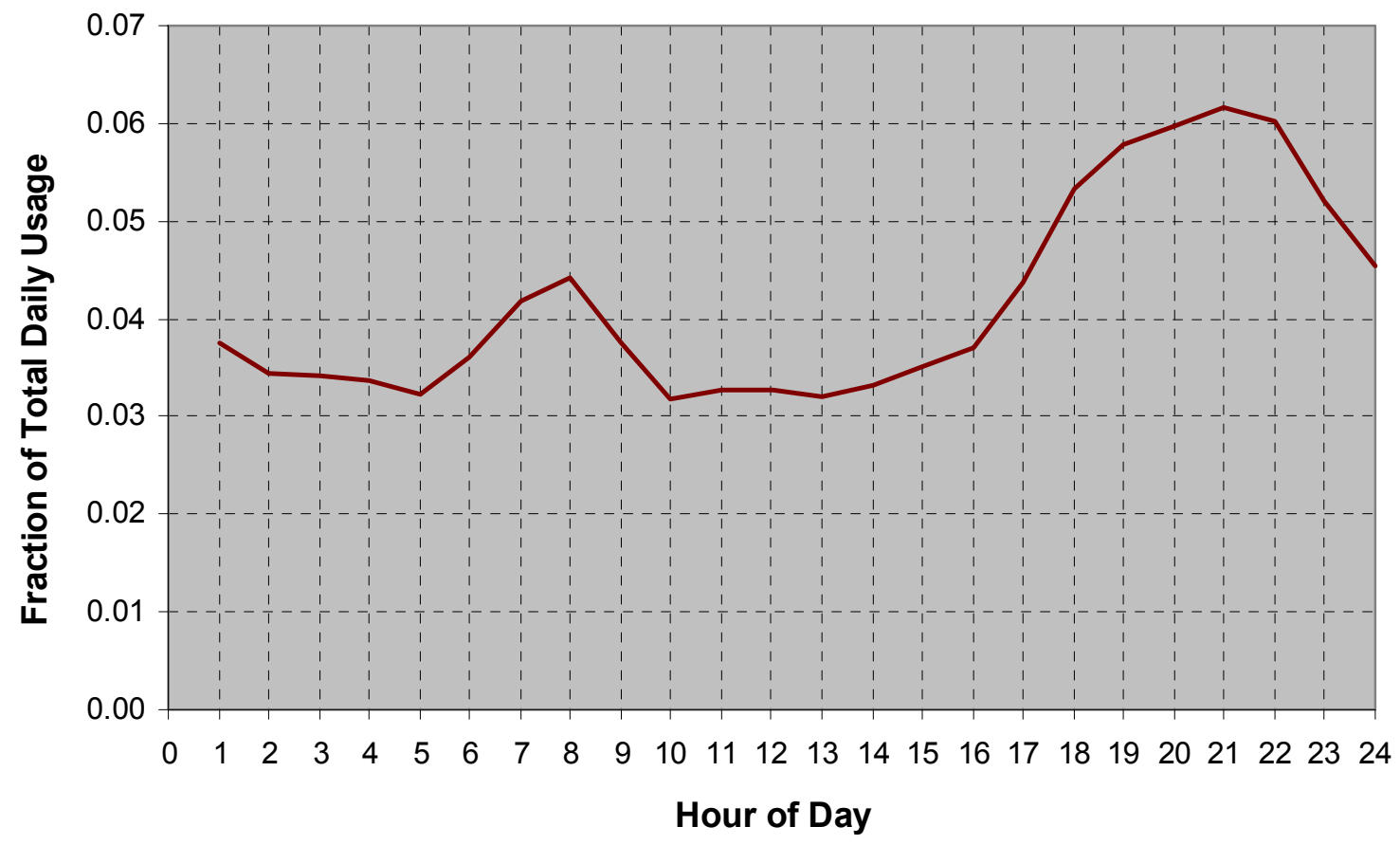

Figure 22. Other appliance and plug load normalized energy use profile 


\section{Site Generation}

A review of data from the Energy Information Administration (DOE 2001a) shows that there is rarely any site electricity generation in a 1990s vintage house. This is a reflection of the low market penetration of site electricity systems. Therefore, all electricity is purchased from the local utility in the Benchmark. As costs for photovoltaic systems and other site electricity systems continue to decline, they are expected to begin to make a significant contribution toward meeting residential energy needs by the year 2020 . Therefore, site electricity generation must be included in the whole-house energy performance analysis of the Prototype.

\section{Modeling the Prototype}

The Prototype is modeled either as-designed or as-built, depending on the status of the project. All parameters for the Prototype model shall be based on final design specifications or measured data, with the following exceptions and clarifications:

- Any house characteristics that are unknown and are not part of the package of energy efficiency improvements shall be the same as the Benchmark.

- The effective leakage area for the Prototype shall be calculated based on blower door testing conducted in accordance with ASTM E779. If the whole-house simulation tool cannot calculate hourly infiltration based on effective leakage area, an annual average natural infiltration rate may be used based on the guidelines in ASHRAE Standard 119 (ASHRAE 1988), Section 5, and ASHRAE Standard 136 (ASHRAE 1993), Section 4. It is recommended that blower door measurements be supplemented with tracer gas testing when possible.

- If the Prototype does not have a cooling system, but there is a non-zero cooling load, then the Prototype shall be modeled assuming a standard 10 SEER air conditioner connected to the heating ducts. If the Prototype does not have a duct system for heating, the air conditioner shall be modeled as a ductless 10 SEER room air conditioner.

- Mechanical ventilation shall be combined with natural infiltration in accordance with Section 4.4 of ASHRAE Standard 136 to determine an approximate combined infiltration rate.

- If the actual EER for the Prototype is not readily available, Equation 12 may be used to make an approximate conversion from SEER to EER (Wassmer 2003):

\section{Equation 12: $\quad$ EER $=-\mathbf{0 . 0 2} \times \mathrm{SEER}^{2}+1.12 \times$ SEER}

- The installation of energy-saving appliances or other equipment may reduce hot-water consumption for certain end uses, reduce the internal sensible and latent loads, or affect the hourly operating profiles. Energy savings calculations for the Prototype must take these effects into account using operating conditions based on rules developed for DOE residential appliance standards (DOE 2003), and the actual performance characteristics of the appliances. The number of cycles per year specified in the appliance standard for clothes washers is adjusted according to the number of bedrooms and the clothes washer capacity, using Equation 13:

\section{Equation 13: Clothes washer cycles per year $=(392) \times\left(1 \frac{1}{2}+N_{b r} / 6\right) \times 12.5 \mathrm{lb} / \mathrm{W}_{\text {test }}$,}

where $\quad \mathrm{W}_{\text {test }}=$ maximum clothes washer test load weight found in 10 CFR part 430, Subpt B, Appendix J1, as a function of the washer capacity in $\mathrm{ft}^{3}$. $\mathbf{N}_{\mathbf{b r}}=$ number of bedrooms. 
A dryer usage factor (DUF) is applied to the clothes washer cycles to determine the number of annual dryer cycles, using Equation 14:

\section{Equation 14: Clothes dryer cycles per year $=$ DUF $x$ Clothes washer cycles per year ,}

$$
\text { where } \quad \text { DUF }=0.84 \text {. }
$$

The dishwasher annual operating cycles are similarly calculated, using Equation 15:

\section{Equation 15: Dishwasher cycles per year $=(215) \times\left(1 / 2+N_{b r} / 6\right)$.}

The Building America Analysis Spreadsheet posted on the Building America Web site automates these calculations, and is strongly recommended for the analysis of water-consuming appliances. The spreadsheet includes tabs to help analysts calculate energy savings for efficient clothes washers, clothes dryers, and dishwashers. It calculates the split between hot water and machine energy based on the EnergyGuide label, estimates dryer energy savings for clothes washers that reduce remaining moisture content, adjusts energy use for the assumption that both hot water and cold water temperatures for the house are usually different than the test values $\left(140^{\circ} \mathrm{F}\right.$ and $60^{\circ} \mathrm{F} / 50^{\circ} \mathrm{F}$ ), and adjusts for the type of controls present (thermostatic control valves, boost heating, cold water only). Both annual average and monthly average hot-water usage are calculated in the spreadsheet.

- Energy savings for a new range/oven may only be credited if an energy factor has been determined in accordance with the DOE test procedures for cooking appliances (DOE 1997). Annual energy consumption is then estimated as the product of the energy factor and the annual useful cooking energy output as defined in the same test procedure. If the energy factor is unknown for a new range/oven, then it shall be assumed that the Prototype energy use for cooking is the same as the Benchmark.

- Modifications to the Benchmark lighting profile and operating hours due to occupancy sensors or other controls may be considered for the Prototype, but negative and/or positive effects on space conditioning load must also be calculated, assuming 100\% of interior lighting energy contributes to the internal sensible load.

- Large end uses that are not part of typical houses (such as swimming pools, Jacuzzis, workshops, etc.) shall not be included in the model of the Prototype. The efficiency of these end uses should be addressed in a separate analysis.

- For the Prototype, all site electricity generation is credited regardless of energy source.

Residential-scale photovoltaic systems, wind turbines, fuel cells, and micro-cogeneration systems are all potential sources of electricity generated on the site. An offset must be applied to this electricity credit equal to the amount of purchased energy used in the on-site generation process. The credit for site generation shall be tracked separately from the whole-house energy analysis and reported as a separate line in the summary tables (discussed later in this section).

\section{Operating Conditions}

The following operating conditions and other assumptions shall apply to both the Prototype house and the Benchmark. The operating conditions are based on the cumulative experience of the authors through their work on Building America, HERS, Codes and Standards, and other residential energy efficiency programs. 
- Thermostat set points based on the optimum seasonal temperature for human comfort as defined in ASHRAE Standard 55-1992 (ASHRAE 1992).

Set point for cooling:

Set point for heating:

Set point for dehumidification (if controlled): $76^{\circ} \mathrm{F}$ with no setup period

$71^{\circ} \mathrm{F}$ with no setback period

$60 \%$ relative humidity

- The natural ventilation schedule shall be set to reflect windows being opened occasionally. In situations where it is a Monday, Wednesday, or Friday and there is a cooling load, windows will be opened if the cooling capacity of outdoor air flow can maintain the cooling set point and the outdoor enthalpy is below the indoor enthalpy (in humid climates). The natural ventilation rate shall be calculated using the Sherman-Grimsrud model. Fifty percent of the maximum open area for windows on each facade and on each floor shall be open. Windows are assumed to be closed once the indoor temperature drops below $73^{\circ} \mathrm{F}$ or if the air change rate exceeds $20 \mathrm{ACH}$. If there are local circumstances that would tend to discourage window operation (pollution, high humidity, security, community standards, etc.), then it is acceptable to use a more appropriate schedule, as long as the same natural ventilation schedule is applied to both the Benchmark and Prototype. Mechanical ventilation fans shall be turned off when natural ventilation is being used.

- Interior shading multiplier $=0.7$ during the cooling season, and 0.85 during the heating season and during swing seasons when both cooling and heating occur. Specific guidelines for defining seasons are presented later in this section.

- If needed for the simulation of a particular design, standard event schedules for domestic hot water are specified in the Building America DHW Event Schedule Spreadsheets posted on the Building America Web site (http://www.eere.energy.gov/buildings/building_america/pa_resources.html). The TMY2 site must be entered to automatically adjust for climate and seasonal effects. These event schedules are only appropriate for standard appliances. Energy-efficient or other non-standard clothes washers and dishwashers may require the generation of a new set of event schedules using the software DHW-calc developed by Kassel University (http://cms.uni-kassel.de/index.php?id=107). Standard input assumptions are documented in the spreadsheets, and should be adjusted based on the actual appliance operating characteristics.

- Internal loads from lighting, appliances, and other equipment were discussed in previous sections. These loads are not necessarily the same for the Prototype and the Benchmark; therefore, they are not considered operating conditions for the purposes of Building America performance analysis.

- Annual cycles for clothes washers, dryers, and dishwashers calculated using the Building America Analysis Spreadsheet posted on the Building America Web site.

- The occupancy schedule is defined with the same level of detail as other internal load profiles. For typical Building America houses, the number of occupants shall be estimated based on the number of bedrooms using Equation 16.

\section{Equation 16: Number of occupants $=0.5 \times \mathrm{N}_{\mathrm{br}}+1.5$}

where $\mathrm{N}_{\mathrm{br}}=$ Number of bedrooms.

Sensible and latent gains shall be accounted for separately, and different loads shall be applied in different space types, as described in Table 14. The occupant heat gains are based on ASHRAE recommendations (ASHRAE 2001). The average hourly occupancy profile is shown in Figure 23, and an example set of detailed hourly occupancy curves is shown in Figure 24. Detailed 
occupancy profiles based on different day and room types are available in spreadsheet format on the Building America Web site

(http://www.eere.energy.gov/buildings/building_america/pa_resources.html). These profiles, which were developed by NREL, are based on the basic ASHRAE occupancy schedule combined with engineering judgment.

Table 14. Peak Sensible and Latent Heat Gain from Occupants (ASHRAE 2001)

\begin{tabular}{|l|c|}
\hline \multicolumn{1}{|c|}{ Multiple Zones } & $\begin{array}{c}\text { Internal Load } \\
\text { (Btu/person/hr) }\end{array}$ \\
\hline Living Area Sensible Load & 230 \\
\hline Living Area Latent Load & 190 \\
\hline Bedroom Area Sensible Load & 210 \\
\hline Bedroom Area Latent Load & 140 \\
\hline \multicolumn{1}{|c|}{ Single Zone } & $\begin{array}{c}\text { Internal Load } \\
\text { (Btu/person/hr) }\end{array}$ \\
\hline Sensible Load & 220 \\
\hline Latent Load & 164 \\
\hline
\end{tabular}

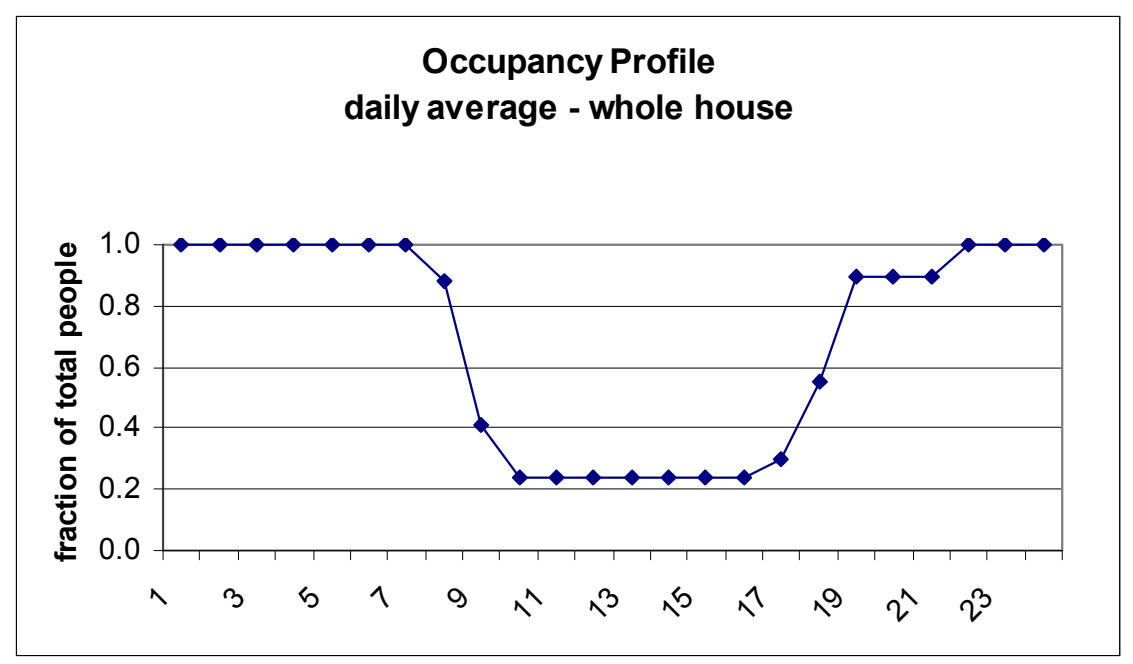

Figure 23. Average hourly load profile from occupants for all day-types and family types (16.5 hours/day/person total) 


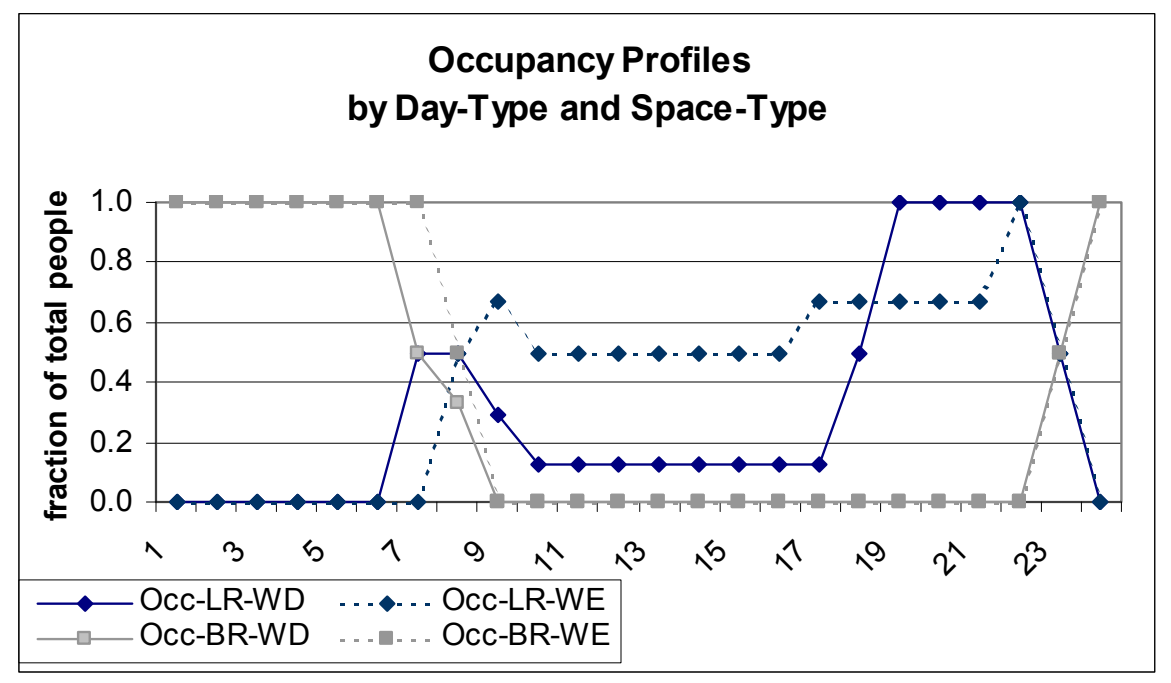

Figure 24. Detailed hourly load profiles resulting from occupants being in different parts of the house on weekdays (WD) and weekends (WE)

- The internal mass of furniture and contents shall be equal to $8 \mathrm{lbs} / \mathrm{ft}^{2}$ of conditioned floor space. For solar distribution purposes, lightweight furniture covering $40 \%$ of the floor area shall be assumed.

- Weather data shall be based on typical meteorological year (TMY2) data from 1961-1990 ${ }^{4}$ or equivalent data for the nearest weather station.

- Heating and cooling shall only occur during certain months of the year in accordance with the guidelines presented below. Alternate operating profiles may be acceptable with sufficient justification. The heating and cooling seasons shall be determined on the basis of the monthly average temperatures (MAT) and the 99\% (annual, not seasonal) winter and summer design temperatures (WDT and SDT, respectively) based on TMY2 data or ASHRAE Fundamentals 2001 for the nearest location, in accordance with the following procedures:

Step 1. MAT Basis

(I) The heating system shall be enabled for a month in which the MAT is less than $66^{\circ} \mathrm{F}$.

(II) The cooling system shall be enabled for a month in which the MAT is greater than $66^{\circ} \mathrm{F}$.

Step 2. WDT and SDT

(I) The heating system shall be enabled in December and January if the WDT is less than or equal to $59^{\circ} \mathrm{F}$, regardless of the outcome in Step 1 above.

(II) The cooling system shall be enabled in July and August regardless of the outcome in Step 1 above.

Step 3. Swing Season Adjustment

(I) If, based on Steps 1 and 2 above, there are consecutive months in which the cooling system is disabled the first month and enabled the following month, then the heating system shall be enabled for the second month.

${ }^{4}$ Analytic Studies Division, National Renewable Energy Laboratory (http://rredc.nrel.gov/solar/old_data/nsrdb/tmy2/). 
(II) If, based on Steps 1 and 2 above, there are consecutive months in which the heating system is disabled the first month and enabled the following month, then the cooling system shall be enabled for the second month.

\section{Reporting Energy Use and Energy Savings}

Reporting energy use and energy savings in a consistent format is an important component of Building America analysis. The following tables shall be supplied with the analysis report for every Building America Prototype.

Table 15 shows an example of a site energy consumption report for a hypothetical Prototype in Virginia, along with all relevant base cases. Similar information based on source energy is presented in Table 16, along with percent energy savings for each end use. End uses are described in more detail in Table 17.

The "Percent of End Use" columns in Table 16 show the Prototype energy use for each end use as a fraction of the appropriate base case. The "Percent of Total" columns show the contribution of each end use toward an overall energy reduction goal. Note that site generation for the Benchmark is always zero.

Source energy shall be determined using Equation 17. For fuels other than electricity and natural gas (such as fuel oil or propane), it is typically not necessary to apply a site to source multiplier.

$$
\begin{aligned}
& \text { Equation 17: Source MBtu }=\mathbf{k W h} * \mathbf{3 . 4 1 2} * \mathbf{M}_{\mathbf{e}} / \mathbf{1 0 0 0}+\text { therms } * \mathbf{M}_{\mathbf{g}} / \mathbf{1 0}+\mathbf{M B t u} * \mathbf{M}_{\mathbf{0}}, \\
& \text { where } \quad \begin{aligned}
\mathrm{M}_{\mathrm{e}}=3.16=\text { site to source multiplier for electricity }(\mathrm{DOE} 2002 \mathrm{~b}) ; \\
\mathrm{M}_{\mathrm{g}}=1.02=\text { site to source multiplier for natural gas }(\mathrm{DOE} 1995) ; \\
\mathrm{M}_{\mathrm{o}}=1.00=\text { site to source multiplier for all other fuels. }
\end{aligned}
\end{aligned}
$$

Table 15. Example Summary of Site Energy Consumption by End Use Using Building America (BA) Research Benchmark

\begin{tabular}{|l|c|c|c|c|c|c|c|c|}
\cline { 2 - 11 } \multicolumn{1}{c|}{} & \multicolumn{9}{c|}{ Annual Site Energy } \\
\cline { 2 - 11 } \multicolumn{1}{c|}{ BA Benchmark } & Region Standard & Builder Standard & \multicolumn{2}{c|}{ BA Prototype } \\
\hline End Use & $(\mathrm{kWh})$ & (therms) & $(\mathrm{kWh})$ & (therms & $(\mathrm{kWh})$ & (therms) & $(\mathrm{kWh})$ & (therms) \\
\hline Space Heating & 11,225 & 0 & 11,286 & 0 & 11,286 & 0 & 4,397 & 0 \\
\hline Space Cooling & 2,732 & 0 & 2,432 & 0 & 2,432 & 0 & 902 & 0 \\
\hline DHW & 4,837 & 0 & 4,838 & 0 & 4,838 & 0 & 1,351 & 0 \\
\hline Lighting & 3,110 & & 3,110 & & 3,110 & & 1,204 & \\
\hline Appliances + Plug & 7,646 & 0 & 7,646 & 0 & 7,646 & 0 & 7,436 & 0 \\
\hline OA Ventilation & 400 & & 400 & & 400 & & 400 & \\
\hline Total Usage & 29,950 & 0 & 29,712 & 0 & 29,712 & 0 & 15,690 & 0 \\
\hline Site Generation & 0 & 0 & 0 & 0 & 0 & 0 & 7,402 & 0 \\
\hline Net Energy Use & 29,950 & 0 & 29,712 & 0 & 29,712 & 0 & 8,289 & 0 \\
\hline
\end{tabular}


Table 16. Example Summary of Source Energy Consumption by End Use Using Building America Research Benchmark

\begin{tabular}{|c|c|c|c|c|c|c|c|c|c|c|}
\hline & & & & & \multicolumn{6}{|c|}{ Source Energy Savings } \\
\hline & \multicolumn{4}{|c|}{ Estimated Annual Source Energy } & \multicolumn{3}{|c|}{ Percent of End-Use } & \multicolumn{3}{|c|}{ Percent of Total } \\
\hline & \begin{tabular}{|c|} 
Benchmark \\
(MBtu/yr)
\end{tabular} & \begin{tabular}{|c|} 
Region \\
(MBtu/yr)
\end{tabular} & $\begin{array}{c}\text { Builder } \\
\text { (MBtu/yr) }\end{array}$ & $\begin{array}{c}\text { Proto } \\
\text { (MBtu/yr) }\end{array}$ & $\begin{array}{c}\text { BA } \\
\text { Base }\end{array}$ & $\begin{array}{l}\text { Reg } \\
\text { Base } \\
\end{array}$ & $\begin{array}{l}\text { Bldr } \\
\text { Base }\end{array}$ & $\begin{array}{c}\text { BA } \\
\text { Base } \\
\end{array}$ & $\begin{array}{l}\text { Reg } \\
\text { Base } \\
\end{array}$ & $\begin{array}{l}\text { Bldr } \\
\text { Base } \\
\end{array}$ \\
\hline Space Heating & 115 & 116 & 116 & 45 & $61 \%$ & $61 \%$ & $61 \%$ & $23 \%$ & $23 \%$ & $23 \%$ \\
\hline Space Cooling & 28 & 25 & 25 & 9 & $67 \%$ & $63 \%$ & $63 \%$ & $6 \%$ & $5 \%$ & $5 \%$ \\
\hline $\mathrm{DHW}$ & 50 & 50 & 50 & 14 & $72 \%$ & $72 \%$ & $72 \%$ & $12 \%$ & $12 \%$ & $12 \%$ \\
\hline Lighting & 32 & 32 & 32 & 12 & $61 \%$ & $61 \%$ & $61 \%$ & $6 \%$ & $6 \%$ & $6 \%$ \\
\hline Appliances + Plug & 78 & 78 & 78 & 76 & $3 \%$ & $3 \%$ & $3 \%$ & $1 \%$ & $1 \%$ & $1 \%$ \\
\hline OA Ventilation & 4 & 4 & 4 & 4 & $0 \%$ & $0 \%$ & $0 \%$ & $0 \%$ & $0 \%$ & $0 \%$ \\
\hline Total Usage & 307 & 304 & 304 & 161 & $48 \%$ & $47 \%$ & $47 \%$ & $48 \%$ & $47 \%$ & $47 \%$ \\
\hline Site Generation & 0 & 0 & 0 & -76 & & & & $25 \%$ & $25 \%$ & $25 \%$ \\
\hline Net Energy Use & 307 & 304 & 304 & 85 & $72 \%$ & $72 \%$ & $72 \%$ & $72 \%$ & $72 \%$ & $72 \%$ \\
\hline
\end{tabular}

Table 17. End-Use Categories

\begin{tabular}{|l|l|l|}
\hline End Use & Potential Electric Usage & Potential Gas Usage \\
\hline Space Heating & $\begin{array}{l}\text { Supply fan during space heating, } \\
\text { HP, HP supplemental heat, water } \\
\text { boiler heating elements, water } \\
\text { boiler circulation pump, electric } \\
\text { resistance heating, HP crankcase } \\
\text { heat, heating system auxiliary }\end{array}$ & $\begin{array}{l}\text { Gas furnace, gas boiler, gas back- } \\
\text { ignition stand-by }\end{array}$ \\
\hline Space Cooling & $\begin{array}{l}\text { Central split-system A/C, } \\
\text { packaged A/C (window or through- } \\
\text { the-wall), supply fan energy during } \\
\text { space cooling, A/C crankcase } \\
\text { heat, cooling system auxiliary }\end{array}$ & Gas absorption chiller (rare) \\
\hline DHW & $\begin{array}{l}\text { Electric hot-water heater, HP } \\
\text { water heater, hot-water circulation } \\
\text { pumps }\end{array}$ & Gas hot-water heater \\
\hline Lighting & Indoor lighting, outdoor lighting & None \\
\hline Equipment & $\begin{array}{l}\text { Refrigerator, electric clothes dryer, } \\
\text { gas clothes dryer (motor), cooking, } \\
\text { miscellaneous }\end{array}$ & Cooking, gas clothes dryer \\
\hline OA Ventilation & $\begin{array}{l}\text { Ventilation fans, supply air fan } \\
\text { during ventilation mode }\end{array}$ & None \\
\hline Site Generation & Photovoltaic electric generation & None \\
\hline
\end{tabular}

Table 18 reports energy savings for individual energy efficiency measures applied to the Prototype, in terms of source energy and energy cost. "Source Energy Savings \%" is determined by comparing the source energy for each measure increment to the source energy for the Benchmark (i.e., the first row). In this column, the incremental savings for each measure are added to the savings for all the previous measures. The final row of the column is the overall energy savings achieved for the Prototype house.

When available, actual energy tariffs for the Prototype house shall be used to determine whole-building energy costs. Energy cost and measure savings are compared with the Builder Standard Practice (representing a real design or set of practices that is currently being used by the builder) rather than with 
the Benchmark. This provides an evaluation of the improvements in the performance of the Prototype compared with that of homes currently being sold by the builder partner.

Reporting of peak hourly energy consumption is also encouraged for every Prototype. Peak energy is based on the hour with the greatest gas or electric energy consumption during the course of one year, as determined by the hourly simulation.

\section{Table 18. Example Measure Savings Report ${ }^{5}$ Using Building America Research Benchmark}

\begin{tabular}{|c|c|c|c|c|c|c|c|c|c|c|c|}
\hline \multirow[b]{4}{*}{ Increment } & & & & & \multirow{3}{*}{\multicolumn{3}{|c|}{$\begin{array}{c}\text { National Average } \\
\text { Energy Cost }\end{array}$}} & & & & \\
\hline & & & & & & & & \multicolumn{4}{|c|}{ Builder Standard (Local Costs) } \\
\hline & \multicolumn{2}{|c|}{ Site Energy } & \multicolumn{2}{|c|}{ Est. Source Energy } & & & & \multicolumn{2}{|c|}{ Energy Cost } & Measure & Package \\
\hline & $(\mathrm{kWh})$ & (therms) & (MBtu) & $\begin{array}{c}\text { Savings } \\
(\%)\end{array}$ & \multicolumn{2}{|r|}{$(\$ / y r)$} & Savings (\%) & $(\$ / y r)$ & \begin{tabular}{c|}
$\begin{array}{c}\text { Savings } \\
(\%)\end{array}$ \\
\end{tabular} & Value $(\$ / y r)$ & $\begin{array}{c}\text { Savings } \\
(\$ / y r)\end{array}$ \\
\hline $\begin{array}{l}\text { Bldg America } \\
\text { Benchmark }\end{array}$ & 29950 & 0 & 306.9 & & $\$$ & 2,995 & & $\$ 2,950$ & & & \\
\hline $\begin{array}{l}\text { Regional Std } \\
\text { Practice }\end{array}$ & 29712 & 0 & 304.4 & $1 \%$ & $\$$ & 2,971 & $1 \%$ & $\$ 2,927$ & & & \\
\hline \begin{tabular}{|l} 
Builder Std \\
Practice (BSP)
\end{tabular} & 29712 & 0 & 304.4 & $1 \%$ & $\$$ & 2,971 & $1 \%$ & $\$ 2,927$ & & & \\
\hline $\begin{array}{l}\text { BSP + } \\
\text { improved walls }\end{array}$ & 27779 & 0 & 284.6 & $7 \%$ & $\$$ & 2,778 & $7 \%$ & $\$ 2,736$ & $7 \%$ & $\$ \quad 190.4$ & 190 \\
\hline $\begin{array}{l}\text { BSP ++ } \\
\text { Low-E Windows }\end{array}$ & 25810 & 0 & 264.5 & $14 \%$ & $\$$ & 2,581 & $14 \%$ & $\$ 2,542$ & $13 \%$ & $\$ 193.9$ & 384 \\
\hline $\begin{array}{l}\text { BSP }++ \\
\text { Smaller A/C (5- } \\
>4 \text { tons) }\end{array}$ & 25420 & 0 & 260.5 & $15 \%$ & $\$$ & 2,542 & $15 \%$ & $\$ 2,504$ & $14 \%$ & 38.4 & 423 \\
\hline $\begin{array}{l}\text { BSP ++ } \\
\text { Inc. Bsmt Wall } \\
\text { Insulation }\end{array}$ & 25170 & 0 & 257.9 & $16 \%$ & $\$$ & 2,517 & $16 \%$ & $\$ 2,479$ & $15 \%$ & 24.6 & 447 \\
\hline \begin{tabular}{|l|} 
BSP ++ \\
Ground Source \\
HP (+DHW) \\
\end{tabular} & 19331 & 0 & 198.1 & $35 \%$ & $\$$ & 1,933 & $35 \%$ & $\$ 1,904$ & $35 \%$ & $\$ \quad 575.1$ & 1,023 \\
\hline \begin{tabular}{|l|} 
BSP ++ \\
Solar DHW \\
\end{tabular} & 17718 & 0 & 181.5 & $41 \%$ & $\$$ & 1,772 & $41 \%$ & $\$ 1,745$ & $40 \%$ & $\$ \quad 158.9$ & 1,181 \\
\hline $\begin{array}{l}\text { BSP ++ } \\
\text { Lighting, Appl. \& } \\
\text { Plug }\end{array}$ & 15690 & 0 & 160.8 & $48 \%$ & $\$$ & 1,569 & $48 \%$ & $\$ 1,545$ & $47 \%$ & $\$ \quad 199.8$ & 1,381 \\
\hline Site Generation & & & & & & & & & & & \\
\hline \begin{tabular}{|l|}
$\mathrm{BSP}++$ \\
$\mathrm{PV}$
\end{tabular} & 8288 & 0 & 84.9 & $72 \%$ & $\$$ & 829 & & 816 & $72 \%$ & $\$ 729.0$ & 2,110 \\
\hline
\end{tabular}

${ }^{5}$ Calculated using national average electric cost $=\$ 0.10 / \mathrm{kWh}$ and national average gas cost $=\$ 0.50 /$ therm. 


\section{References}

Abrams, D.W., and Shedd, A.C. 1996. "Effect of Seasonal Changes in Use Patterns and Cold Inlet Water Temperature on Water Heating Load.” ASHRAE Transactions, AT-96-18-3.

American Society of Heating, Refrigerating, and Air-Conditioning Engineers (ASHRAE). 2001. Fundamentals Handbook. Atlanta, GA: ASHRAE.

American Society of Heating, Refrigerating, and Air-Conditioning Engineers (ASHRAE). 1999. HVAC Applications Handbook. Atlanta, GA: ASHRAE.

American Society of Heating, Refrigerating, and Air-Conditioning Engineers (ASHRAE). 1993. A Method of Determining Air Change Rates in Detached Dwellings, ASHRAE Standard 136-1993, Atlanta, GA.

American Society of Heating, Refrigerating, and Air-Conditioning Engineers (ASHRAE). 1988. Air Leakage Performance for Detached Single-Family Residential Buildings, ASHRAE Standard 1191988, Atlanta, GA.

American Society of Heating, Refrigerating, and Air-Conditioning Engineers (ASHRAE). 2001. "Method of Test for Determining the Design and Seasonal Efficiencies of Residential Thermal Distribution Systems," Proposed ASHRAE Standard 152P, Atlanta, GA.

American Society of Heating, Refrigerating, and Air-Conditioning Engineers (ASHRAE). 1992. "Thermal Environmental Conditions for Human Occupancy," ASHRAE Standard 55-1992, Atlanta, GA.

Becker, B.R. and K.E. Stogsdill. 1990. "Development of Hot Water Use Data Base.” ASHRAE Transactions, Vol. 96, Part 2, pp. 422-427. American Society of Heating, Refrigerating and Air Conditioning Engineers, Atlanta, GA.

Burch, J., and Salasovich, J. 2002. "Flow Rates and Draw Variability in Solar Domestic Hot Water Usage." Proceedings of the Solar 2002 Conference Including Proceedings of the 31st ASES Annual Conference and Proceedings of the 27th National Passive Solar Conference, 15-20 June 2002, Reno, Nevada. Boulder, CO: American Solar Energy Society, Inc. (ASES); pp. 287-292; NREL Report No. CP-550-31779.

Burch, J., and Erickson, P. 2004 (Draft). "Deriving Inputs for Storage Tank Water Heater Models from Rating Data.” Conference paper. Golden, CO: National Renewable Energy Laboratory.

California Energy Commission. 2002. California Building Energy Efficiency Standards, Part 1, Measure Analysis and Life Cycle Cost, CEC, Sacramento, CA.

Christensen, C., Barker, G., and Thornton, J. 2000. Parametric Study of Thermal Performance of Integral Collector Storage Solar Water Heaters. NREL Report No. CP-550-28043. Conference paper. Golden, CO: National Renewable Energy Laboratory.

Eley Associates. 2002. Visual DOE Version 3.1. San Francisco, CA: Eley Associates.

Environmental Protection Agency (EPA). 2006. Savings Calculator-Dehumidifier. Available online at http://www.energystar.gov/ia/business/bulk_purchasing/bpsavings_calc/CalculatorConsumerDehumi difier.xls. Washington, DC: Environmental Protection Agency. 
Huang, J., and Gu, L. 2002 (Draft). Prototypical Residential Buildings to Represent the US Housing Stock. Berkeley, CA: Lawrence Berkeley National Laboratory.

Hendron, R., Anderson, R., Judkoff, R., Christensen, C., Eastment, M., Norton, P., Reeves, P., Hancock, E. 2004. Building America Performance Analysis Procedures, Rev. 1. NREL/TP-550-35567, NREL, Golden, CO.

International Code Council (ICC). 2003. International Energy Conservation Code 2003. Falls Church, VA: ICC.

Kolb, G. October 2003. Private communication. Sandia National Laboratories, Albuquerque, NM.

Manclark, B., and Nelson, M. 1992. The Grays Harbor PUD Compact Fluorescent Maximization Study. Grays Harbor, WA: Grays Harbor Public Utility District.

National Renewable Energy Laboratory (NREL). 1995. Solar Radiation Data Manual for Buildings. NREL/TP-463-7904. Golden, CO: NREL.

Navigant Consulting. 2002. U.S. Lighting Market Characterization: Volume 1: National Lighting Inventory and Energy Consumption Estimate. Washington, DC: Navigant Consulting.

Parker, D. 2002. Research Highlights from a Large Scale Residential Monitoring Study in a Hot Climate (and personal communication). FSEC-PF369-02. Cocoa, FL: Florida Solar Energy Center.

Parker, D., et al. September 2000. FPC Residential Monitoring Project: Assessment of Direct Load Control and Analysis of Winter Performance. Prepared for the Florida Power Corporation, FSEC-CR1112-99. Cocoa, FL.

Pratt, R., Conner, C., Richman, E., Ritland, K., Sandusky, W., and Taylor, M. 1989. "Description of Electric Energy Use in Single-Family Residences in the Pacific Northwest - End-Use Load and Consumer Assessment Program (ELCAP)", DOE/BP-13795-21, Pacific Northwest National Laboratory, Richland, WA.

Residential Energy Services Network (RESNET). 2002. "Mortgage Industry National Home Energy Rating Systems Accreditation Standards.” Chapter 3, pp. 29-54. San Diego, CA: RESNET.

Southern California Edison (SCE). 1993. Final Report: Residential Lighting Study (Inventory Results). Rosemead, CA: SCE.

U.S. Department of Energy (DOE). 1996. Residential Lighting Use and Potential Savings. DOE/EIA0555(96)/2. Washington, DC: U.S. DOE.

U.S. Department of Energy (DOE). November 1999. "1997 Residential Energy Consumption Survey”. Available online at http://www.eia.doe.gov/emeu/recs/1997. Washington, DC: U.S. DOE.

U.S. Department of Energy (DOE) (July 2002b), “2002 Buildings Energy Databook” online at http://btscoredatabook.eren.doe.gov/; see the 2003 databook at http://btscoredatabook.eren.doe.gov/ (accessed May 2004). Washington, DC: U.S. DOE.

U.S. Department of Energy (DOE). December 1995. Measuring Energy Efficiency in the United States Economy: A Beginning. Chapter 7. Available online at http://www.eia.doe.gov/emeu/efficiency/ee report_html.htm (accessed May 2004). Washington, DC: U.S. DOE. 
U.S. Department of Energy (DOE). 2001a. Annual Energy Outlook 2002. Washington, DC: U.S. DOE.

U.S. Department of Energy (DOE). May 2002a. "Residential Energy Efficiency and Appliance Standards." http://www.eere.energy.gov/consumerinfo/refbriefs/ee8.html (accessed May 2004). Washington, DC: U.S. DOE.

U.S. Department of Housing and Urban Development (HUD). 1982. "Minimum Property Standards for One- and Two-Family Living Units.” No. 4900.1-1982. Washington, DC: HUD.

Wassmer, M. 2003. “A Component-Based Model for Residential Air Conditioner and Heat Pump Energy Calculations". Masters Thesis, University of Colorado at Boulder. 


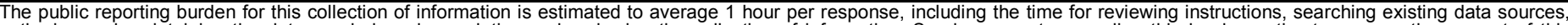

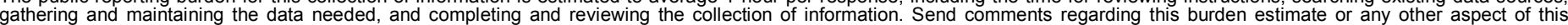

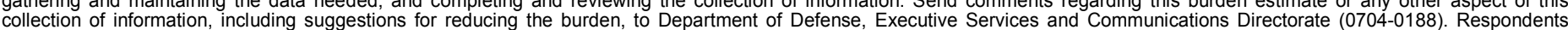

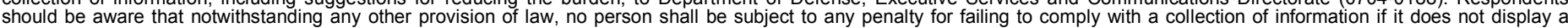

should be aware that notwithstanding

PLEASE DO NOT RETURN YOUR FORM TO THE ABOVE ORGANIZATION.

\begin{tabular}{l|l|l|l} 
1. REPORT DATE $(D D-M M-Y Y Y Y)$ & 2. REPORT TYPE & 3. DATES COVERED (FrOm - TO)
\end{tabular}

August 2007

Technical Report

4. TITLE AND SUBTITLE
Building America Research Benchmark Definition:

Updated August 15, 2007

5a. CONTRACT NUMBER

DE-AC36-99-G010337

5b. GRANT NUMBER

5c. PROGRAM ELEMENT NUMBER

6. AUTHOR(S)

R. Hendron 5d. PROJECT NUMBER

NREL/TP-550-42011

5e. TASK NUMBER

BET78004

5f. WORK UNIT NUMBER
7. PERFORMING ORGANIZATION NAME(S) AND ADDRESS(ES)

National Renewable Energy Laboratory

1617 Cole Blvd.

Golden, CO 80401-3393
8. PERFORMING ORGANIZATION REPORT NUMBER

NREL/550-42011

9. SPONSORING/MONITORING AGENCY NAME(S) AND ADDRESS(ES)

10. SPONSOR/MONITOR'S ACRONYM(S) NREL

11. SPONSORING/MONITORING AGENCY REPORT NUMBER

12. DISTRIBUTION AVAILABILITY STATEMENT

National Technical Information Service

U.S. Department of Commerce

5285 Port Royal Road

Springfield, VA 22161

13. SUPPLEMENTARY NOTES

14. ABSTRACT (Maximum 200 Words)

To track progress toward aggressive multi-year whole-house energy savings goals of $40-70 \%$ and onsite power production of up to $30 \%$, DOE's Residential Buildings Program and NREL developed the Building America Research Benchmark in consultation with the Building America industry teams. The Benchmark is generally consistent with mid-1990s standard practice, as reflected in the Home Energy Rating System (HERS) Technical Guidelines (RESNET 2002), with additional definitions that allow the analyst to evaluate all residential end-uses, an extension of the traditional HERS rating approach that focuses on space conditioning and hot water. Unlike the reference homes used for HERS, EnergyStar, and most energy codes, the Benchmark represents typical construction at a fixed point in time so it can be used as the basis for Building America's multi-year energy savings goals without the complication of chasing a 'moving target'.

15. SUBJECT TERMS

benchmark; building america; home energy rating system; hers

\begin{tabular}{|c|c|c|c|c|}
\hline \multicolumn{3}{|c|}{ 16. SECURITY CLASSIFICATION OF: } & \multirow{2}{*}{$\begin{array}{l}\text { 17. LIMITATION } \\
\text { OF ABSTRACT } \\
\text { UL }\end{array}$} & \multirow{2}{*}{$\begin{array}{l}\text { 18. NUMBER } \\
\text { OF PAGES }\end{array}$} \\
\hline $\begin{array}{l}\text { a. REPORT } \\
\text { Unclassified }\end{array}$ & $\begin{array}{l}\text { b. ABSTRACT } \\
\text { Unclassified }\end{array}$ & $\begin{array}{l}\text { c. THIS PAGE } \\
\text { Unclassified }\end{array}$ & & \\
\hline
\end{tabular}

19a. NAME OF RESPONSIBLE PERSON

19b. TELEPHONE NUMBER (Include area code) 


\section{A Strong Energy Portfolio for a Strong America}

Energy efficiency and clean, renewable energy will mean a stronger economy, a cleaner environment, and greater energy independence for America. Working with a wide array of state, community, industry, and university partners, the U.S. Department of Energy's Office of Energy Efficiency and Renewable Energy invests in a diverse portfolio of energy technologies.

\section{Research and Development of Buildings}

Our nation's buildings consume more energy than any other sector of the U.S. economy, including transportation and industry. Fortunately, the opportunities to reduce building energy useand the associated environmental impacts—are significant.

DOE's Building Technologies Program works to improve the energy efficiency of our nation's buildings through innovative new technologies and better building practices. The program focuses on two key areas:

\section{- Emerging Technologies} Research and development of the next generation of energy-efficient components, materials, and equipment

- Technology Integration Integration of new technologies with innovative building methods to optimize building performance and savings

For more information contact: EERE Information Center 1-877-EERE-INF (1-877-337-3463) www.eere.energy.gov

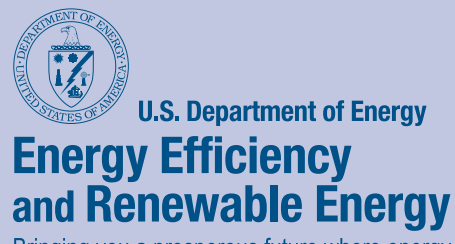

Bringing you a prosperous future where energy is clean, abundant, reliable, and affordable

An electronic copy of this publication is available on the Building America Web site at www.buildingamerica.gov

\section{Visit our Web sites at:}

\section{Building
U.S. Department of Energy
Research Toward Zero Energy Homes}

Building America Program

George S. James • New Construction • 202-586-9472• fax: 202-586-8134 • e-mail: George.James@ee.doe.gov

Terry Logee • Existing Homes • 202-586-1689 • fax: 202-586-4617• e-mail: terry.logee@ee.doe.gov

Lew Pratsch • Integrated Onsite Power • 202-586-1512 • fax: 202-586-8185 • e-mail: Lew.Pratsch@hq.doe.gov

Building America Program • Office of Building Technologies, EE-2J • U.S. Department of Energy • 1000 Independence Avenue, S.W. • Washington, D.C. 20585-0121・ www.buildingamerica.gov

Building Industry Research Alliance (BIRA)

Robert Hammon • ConSol • 7407 Tam 0'Shanter Drive \#200 • Stockton, CA 95210-3370 • 209-473-5000 • fax: 209-474-0817• e-mail: Rob@consol.ws•www.bira.ws

Building Science Consortium (BSC)

Betsy Pettit • Building Science Consortium (BSC) • 70 Main Street • Westford, MA $01886 \bullet 978-589-5100 \bullet$ fax: 978-589-5103 • e-mail: Betsy@buildingscience.com • www.buildingscience.com

Consortium for Advanced Residential Buildings (CARB)

Steven Winter • Steven Winter Associates, Inc. • 50 Washington Street • Norwalk, CT $06854 \bullet 203-857-0200 \bullet$ fax: 203-852-0741 • e-mail: swinter@swinter.com • www.carb-swa.com

\section{Davis Energy Group}

David Springer • Davis Energy Group • 123 C Street • Davis, CA 95616 • 530-753-1100 • fax: 530-753-4125• e-mail: springer@davisenergy.com • deg@davisenergy.com • www.davisenergy.com/index.html

IBACOS Consortium

Brad Oberg • IBACOS Consortium • 2214 Liberty Avenue • Pittsburgh, PA $15222 \bullet 412-765-3664 \bullet$ fax: 412-765-3738 • e-mail: boberg@ibacos.com • www.ibacos.com • IBACOS provided technical support for TNAH '07

Industrialized Housing Partnership (IHP)

Subrato Chandra • Florida Solar Energy Center • 1679 Clearlake Road • Cocoa, FL 32922 • 321-638-1412 • fax: 321-638-1439 • e-mail: subrato@fsec.ucf.edu • www.baihp.org • IHP provided on-site support for TNAH '07

National Council of the Housing Industry (NCHI) of the NAHB

Tucker Bernard • NCHI • The Supplier $100 \bullet$ National Association of Home Builders (NAHB) • 1201 15th St. NW, Washington, D.C. 20005 • 800-368-5242 ext. 8519• e-mail: tbernard@nahb.org • www.nahb.org

National Renewable Energy Laboratory

Ren Anderson • 1617 Cole Boulevard, MS-1725 • Golden, C0 80401 • 303-384-7433 • fax: 303-384-7540 •

e-mail: ren_anderson@nrel.gov • www.nrel.gov

Tim Merrigan • 1617 Cole Boulevard, MS-1725 • Golden, C0 80401 • 303-384-7349 • fax: 303-384-7540 •

e-mail: tim_merrigan@nrel.gov• www.nrel.gov

Oak Ridge National Laboratory

Pat M. Love • P.O. Box $2008 \bullet$ One Bethel Valley Road • Oak Ridge, TN 37831 • 865-574-4346 • fax: 865-574-9331 • e-mail: lovepm@ornl.gov• www.ornl.gov

Pacific Northwest National Laboratory

Michael C. Baechler • 620 Southwest 5th, Suite $810 \bullet$ Portland, OR $97204 \bullet 503-417-7553 \bullet$ fax: 503-417-2175•

e-mail: michael.baechler@pnl.gov• www.pnl.gov

Produced for the U.S. Department of Energy (DOE) by the National Renewable Energy Laboratory, a DOE national laboratory. September 2007 - NREL/TP-550-42011

Printed with a renewable-source ink on paper containing at least $50 \%$ wastepaper, including $20 \%$ postconsumer waste. 